\title{
Performance Consequences of Privatizing Egyptian State-Owned Enterprises: The Effect of Post-Privatization Ownership Structure on Firm Performance
}

\author{
Mohammed Omran \\ Arab Academy for Science \& Technology, Egypt \\ and \\ Arab Monetary Fund, U.A.E.
}

This paper evaluates the financial and operating performance of newly privatized Egyptian state-owned enterprises and determines whether such performance differs across firms according to their new ownership structure. The Egyptian privatization program provides unique post-privatization data on different ownership structures. Since most studies do not distinguish between the types of ownership, this paper provides new insight into the impact that post-privatization ownership structure has on firm performance. The study covers 69 firms, which were privatized between 1994 and 1998. For these newly privatized firms, this study documents significant increases in profitability, operating efficiency, capital expenditures, and dividends. Conversely, significant decreases in employment, leverage, and risk are found, although output shows an insignificant decrease following privatization. The empirical results also show that Egyptian state-owned enterprises, which were sold to anchor-investors and employee shareholder associations, seem to outperform other types of privatization, such as minority and majority initial public offerings (JEL: G32, L33).

Keywords: privatization, SOEs, Egypt, and ownership structure.

\footnotetext{
*The author would like to thank Juliet D'Souza, Scott Linn and William Megginson for their suggestions; Sarah Allen, Ali Bolbol, Harry Churchill, and Suzanne Farrar for their research assistance; my colleagues at the Arab Academy for Science and Technology for research assistance; the Fulbright Commission office in Egypt for financial support; the Michael F. Price College of Business at the University of Oklahoma for their hospitality; and the Public Enterprises Information Center and the Capital Market Authority in Egypt for providing the data. The views expressed in this paper are those of the author and do not necessarily reflect the views of the Arab Monetary Fund.
}

(Multinational Finance Journal, 2004, vol. 8, no. 1 \& 2, pp. 73-114)

(C) Multinational Finance Society, a nonprofit corporation. All rights reserved. DOI: $10.17578 / 8-1 / 2-3$ 


\section{Introduction}

Over the past few decades, privatization has been an important area for both theoretical and empirical research. As most developing countries have shifted to market-oriented economies and adopted privatization policies to improve the performance of their state-owned enterprises (SOEs), there is now extensive literature and evidence on whether privatization improves firm performance and contributes to the gross domestic product (GDP) growth. Most studies, however, have not made a distinction between the types of firm ownership, whether individual owners, or even relatively homogeneous groups of owners. Instead, ownership tends to be treated as a relatively simple categorical concept. ${ }^{1}$ In an effort to provide new insight into the impact of changed ownership structures on firm performance, this study focuses on the Egyptian privatization program. The program provides unique data sets that make it possible to assess the impact of different ownership structures in the post-privatization period on firm performance. ${ }^{2}$ The two main objectives of this paper are (i) to examine the financial and operating performance of newly privatized Egyptian firms in order to determine whether privatization has a positive impact on firm performance and to examine the extent to which these results are consistent with previous findings for other countries, and equally important, (ii) to test whether the performance of privatized firms differs according to the type of ownership structure during the post-privatization period.

Between 1960 and 1990, SOEs handled most of Egypt's economic activity under the direction of various ministries. Poor management and weak capitalization of SOEs inevitably had a negative effect on their efficiency and financial viability, Road (1997). In an effort to improve the Egyptian economy, Egypt launched a privatization program in 1991 as a part of its wider economic reform program. The first step in Egypt's privatization program was to cut off subsidies to SOEs, followed by removing them from direct ministerial control, Field (1995). Under the

1. For example, state versus private ownership and domestic versus foreign ownership.

2. Two methods of sale (full and partial privatization) were executed to provide four marked types of ownership. Full privatization yielded three types: (1) majority initial public offerings-at least $51 \%$ of a firm's shares were sold to public via the stock market, (2) employee shareholder associations (ESAs)-the majority of a firm's shares were sold to either ESAs, or (3) anchor-investors. Partial privatization yielded the fourth type: (4) minority initial public offering-less than $50 \%$ of a firm's shares were sold to the public via the stock market with the rest remaining in the government's hands. 
government's strategy for divestment of SOEs, three approaches were undertaken initially: the first was to sell shares through the domestic stock market as minority and majority initial public offerings (IPOs), the second was to sell strategic stakes of shares to anchor-investors through public auction, and the third was to sell firms to employee shareholder associations (ESAs), McKinney (1996). ${ }^{3}$

The choice of privatization method basically depends on market conditions, public opinion, and government objectives. But in fact, the general preference-when implementing the policy of economic liberalization or making it the first step toward complete privatization of an SOE-is to sell shares in the capital market instead of making direct sales to individuals. However, when the stock market is not active (i.e., the absorption capacity of the market is limited), the government will usually select direct sales as an alternative. Also, this method is favored when the potential buyers of the firm are known, thus making negotiations easier since the government is familiar with their ability to add value to the firm, such as penetrating new markets, bringing new technology, or adding more capital investment.

A government sale of SOEs to ESAs should have a positive impact on labor, which is necessary in building a pro-privatization constituency from within a traditional seat of hostility. In addition, privatization through ESAs tends to be industry and firm specific. In other words, it might be easy to privatize small firms that are labor intensive via ESAs, but it is hardly feasible to do the same in, for example, engineering firms, which are generally large, and output is capital intensive. Last, in the case of partial privatization (minority IPOs), where the government sells only a limited stake via the stock market, the government remains influential in certain SOEs because of their importance to social welfare (i.e., pharmaceuticals and mills). Profits represent substantial rents in these industries-a fact that might create political opposition to full privatization activities.

The privatization process in Egypt begins with an analysis of the most suitable means of privatization for a particular firm. Firm experts or advisors usually carry this out, and then the boards of directors of affiliated firms review the results of the studies before the necessary legal procedures are put into motion. For example, a sale through the stock market involves the holding company's convening an extraordinary

3. Besides these approaches, firms that suffered from a large debt burden were not deemed economically viable and were liquidated. 
general assembly meeting to look into the proposal for the sale of 51 percent or more of an affiliated SOE through the stock market. ${ }^{4}$ The decision is determined by unanimous agreement; once the decision to sale is agreed upon, the holding company then prepares financial statements and evaluations to be reviewed by a designated government committee. This committee is responsible for evaluating the SOE and determining the market value of its shares. The holding company selects the promoter and the broker, places an advertisement in the newspaper, and then secures investors' requests through the stock market.

As for an SOE sale to an ESA, the process includes the preparation of an evaluation of the firm and its approval by the company's general assembly. The ministerial privatization committee (MPC) also approves the evaluation before a sales contract can be drawn up with the conditions for the transfer of ownership and the payment terms. The ESA is given a discount ranging between 10 to 20 percent of the fair market value and a ten-year mortgage for the balance at a simple interest rate. The holding company provides support to the ESA in different forms, such as orientation, and management training along with technical support and investment advise. The holding company also offer the ESA the opportunity to finance its purchases of equipment and other improvements needed to allow the company to continue to grow and maintain a workforce.

The sale to anchor-investors, however, is conducted differently. The process includes agreement to the sale of majority shares to anchor-investors by the extraordinary general assembly of the holding company. The promoter is then selected, an information memorandum is prepared, and promotion announcements are published in local and international papers. This allows potential investors to obtain information and disclosure documents on the firm offered for sale. The advertisement specifies the conditions of the sale and allows investors to carry out technical, financial, and legal analysis of the firm. The buyers submit their offers, and the holding company forms a committee to receive and open their bids. A decision committee is also formed, and the final decision is made following the technical and financial evaluation of all offers. A recommendation is made to the holding company's board of directors, who then submits its analysis and conclusions to the general assembly for their decision before submittal

4. An ordinary general assembly is required for cases of minor stakes, i.e., when less than 50 percent of the firm is sold. 
to the MPC. The decision is then reviewed by the MPC, who issues the ultimate determination. At that point, the holding company begins to prepare the sales contract. Ownership is transferred to the investors, and the terms of the contract are executed.

Using a sample of 69 Egyptian firms that were privatized between 1994 and 1998, this study finds significant increases in profitability, operating efficiency, capital expenditures, and dividends, and a significant decline in leverage. ${ }^{5}$ The study also finds a significant decline in employment and risk. The insignificant change that privatized firms exhibit in output and asset turnover tends to contradict the literature and theoretical arguments. Equally important, this study finds that the performance of firms differs according to the type of ownership structure in the post-privatization period. The empirical findings suggest that firms, which have concentrated ownership or are a homogeneous group- that is, those firms sold to anchor-investors and ESAs -seem to outperform dispersed ownership firms (majority IPOs). In addition, this study finds that private ownership firms outperform state-controlled ones (minority IPOs).

The results of this study have important policy implications for the privatization method the government should adopt to achieve the most beneficial outcome when selling future SOEs. If the aspiration of the government is aimed at improving the efficiency of privatized firms, it should not continue to be a shareholder in privatized firms. Hence, full privatization is supported over partial privatization. Furthermore, policy makers have to realize that privatization per se, does not promote efficiency, but privatization should be accompanied by effective corporate governance. In this context, dispersed ownership, in contrast to concentrated ownership, might result in a split between management and shareholders. Therefore, unless an effective mechanism for legal protection of minority ownership rights is put into place, the populace is likely to see a weak and non-transparent corporate governance system, which will have a negative effect on firm performance.

The remainder of this paper is divided into four sections. Section II provides a summary of the impact of privatization and ownership structure on firm performance and the research propositions. Data and methods used are discussed in section III. Section IV reports the empirical findings and analysis. Conclusions are given in Section V.

5. D'Souza and Megginson (1999) show insignificant changes in the level of employment; see Megginson and Netter (2001) for a list of recent works on privatization. 


\section{Background and Research Propositions}

Many comprehensive academic studies have been undertaken regarding the impact of privatization upon firm performance. These studies can be separated into two categories: the first category concentrates on examining the financial and operating performance of privatized firms, while the other comprises more recent studies that examine the impact of different post-privatization ownership structures on firm performance. Each of these categories will now be briefly reviewed.

\section{A. Financial and Operating Performance}

The financial and operating performance of privatized firms has been studied at many levels: case studies of individual firms; studies of individual countries; and international studies, encompassing both emerging and developed markets.

At the case study level, Eckel et al. (1997) analyze the effects of privatization on the performance of British Airways and argue that when a firm is privatized several factors change simultaneously, such as a firm's ownership and objectives. These factors, among others, ultimately improve the economic efficiency of the firm. Ramamurti (1997) also finds a significant improvement in labor productivity of Argentine national freight following privatization although that improvement was accompanied by a significant employment decrease.

As far as studies on individual countries are concerned, Martin and Parker (1995) find mixed results in performance-in terms of profitability and efficiency-for 11 privatized firms in the UK. LaPorta and Lopez-de-Silanes (1997) report significant improvements in output and sales efficiency, and a significant decrease in the level of employment of Mexican privatizations. In contrast, Harper (2001) documents different findings for 178 Czech firms that were included in the first wave of voucher privatization. He concludes that profitability and efficiency decrease immediately following privatization.

Extensive works address the impact of privatization on a broader international level, including both emerging and developed countries. In this context, Galal, Jones, Tandon, and Vogelsang (1992) document net welfare gains in 11 out of 12 privatized firms located in developing and developed economies. In larger scale and more comprehensive studies, Megginson, Nash, and Randenborgh (1994), Boubakri and Cosset (1998), and D'Souza and Megginson (1999) find significant 
improvements in profitability, operating efficiency, capital investment spending, output, employment levels, and dividends, while they observe a decline in leverage.

From the above studies, it is clear that the objective of any privatization program is to increase the ability of firms to achieve their goals. Hence, this proposition is examined, inferring that:

Privatization increases profitability, operating efficiency, capital expenditures, output, and dividends, while leverage will decline. Moreover, privatization might affect the level of employment and the financial risk of the firm.

\section{B. The Impact of Post-privatization Ownership Structure}

On the other hand, few empirical studies look at the impact of different post-privatization ownership structures on firm performance. In this context, Barberies et al. (1996) examine performance changes in 452 Russian privatized firms and conclude that changes in ownership and management styles are likely to lead to a value-maximizing restructuring. For 706 Czech Republic privatized firms, Claessens et al. (1997) find that concentrated ownership structure, ownership by local investors, and ownership by bank-sponsored investment privatization funds increase profitability and Tobin's $q$. Earle (1998), in a study on Russian industrial enterprises, documents that private ownershiprelative to state ownership-has a positive impact on labor productivity. He also finds that most improvements in labor productivity is due to the positive effects of managerial and employee ownership. Gupta (2001), in a study on partial privatization in India, indicates that the fraction of equity that is private in a given year has a positive and statistically significant impact on profitability and productivity. In a recent study, Kocenda and Svejnar (2002) indicate that, in the post-privatization period, private ownership, relative to state ownership, tends to be associated with superior performance in terms of certain profitability and efficiency indicators.

In light of the above, it seems that few previous studies have focused on ownership structure. Adding to this literature, the analysis is extended to examine the impact of different types of ownership structure on firm performance in the post-privatization period. Since ownership appears to be a very important factor in determining post-privatization performance, types of privatized firms are 
distinguished according to their new ownership structure. Owners of fully privatized firms, who pay greater attention to profit goals through increased capital investment spending, find that their firms have increased output and efficiency followed by increased profitability; e.g., Boubakri and Cosset (1998).

Additionally, the property rights theory asserts that fully private firms perform better than mixed-ownership firms because of the conflict between private and public shareholders in the latter, which inhibits the monitoring of management, e.g., Boardman and Vinning (1989). Also, Boycko et al. (1996) argue that the higher the fraction of an SOE sold, the lower the possibility that politicians will directly interfere, meaning that any benefits from partial privatization will be minimal. Many researchers also state that firm performance improves when ownership and managerial interests are merged through concentration of ownership; e.g., Walking and Long (1984), Agrawal and Mandelker (1987), Muscarella and Vetsuypens (1990), Castianas and Helfat (1991), Oswald and Jahera (1991) and Baker and Weiner (1992). When major shareholdings are acquired, the control cannot be disputed. Anderson et al. (1997) claim that a significant concentration of ownership might lower, or even completely eliminate, agency costs and offer better control of firms, which tends to occur in privatizations without large numbers of shareholders- such as anchor-investors and ESAs. Moreover, full and concentrated ownership implies lower resistance to restructuring, e.g., Jelic et al. (2003). From the preceding discussion, the following proposition is examined:

Full and concentrated ownership results in better performance compared with partial and dispersed ownership.

\section{Data and Methodology}

\section{A. Data}

The data set for this study was obtained by analyzing Egyptian firms that had been privatized by June 1998 and had at least two years of both pre- and post-privatization data. ${ }^{6}$ As seen in table 1, panel A, the total

6. Although a minimum two years pre- and post-privatization are required, 90 percent of the sample privatized firms had 3 years pre- and post-privatization data. Just 10 percent of the sample had only 2 years data. 
number of privatized firms reached 76 by the end of June 1998. Of these, 35 firms had been sold as majority IPOs in the stock market, and 18 firms had been partially privatized. That is, minority stakes were sold in the stock market. Additionally, 13 firms had been sold to ESAs, while another 10 firms had been sold to anchor-investors. No data were available for four out of the ten anchor-investor firms and one ESA firm. Further, two majority firms witnessed mergers with other private firms after privatization. Hence, it would be appropriate to exclude these seven firms from the analysis. The sample thus contains 69 privatized firms: 33 majority IPO, 18 minority IPO, 12 ESA, and 6 anchor-investor. The number of the Egyptian privatized firms, classified by industry and size, are given in panels B and C. The distribution of firms according to the type of industry in which each firm operates shows that the sample is indeed well diversified since it exhibits a wide dispersion across different industries. At the same time, firm size seems to differ according to the privatization method of sales. Pre-privatization data were obtained from the Public Sector Information Center, while the Egyptian Capital Market Authority provided data for the post-privatization period.

\section{B. Methodology}

A wide range of financial measures is used test whether firms perform better after privatization and whether the different types of ownership structure in the post-privatization period explain the variation in performance across privatized firms. These are:

\section{Profitability.}

The first measure used for profitability is real earnings before interest and tax (EBIT), deflated using the appropriate consumer price index (CPI) values and normalized to equal 1.00 in year 0 ; i.e., the other annual figures are expressed as a ratio of net income of the privatization year. The other three profitability measures are return on sales (ROS), return on assets (ROA), and return on equity (ROE), computed as the ratio of EBIT to sales, assets, and the book value of equity, respectively. These profitability ratios are calculated using profit before interest, tax, and extraordinary items instead of using net income. This is because net income might be affected by several variables: tax credits or carryforwards that do not relate to the current year's performance; the sale of assets prior to privatization and then reporting the capital gains in the 


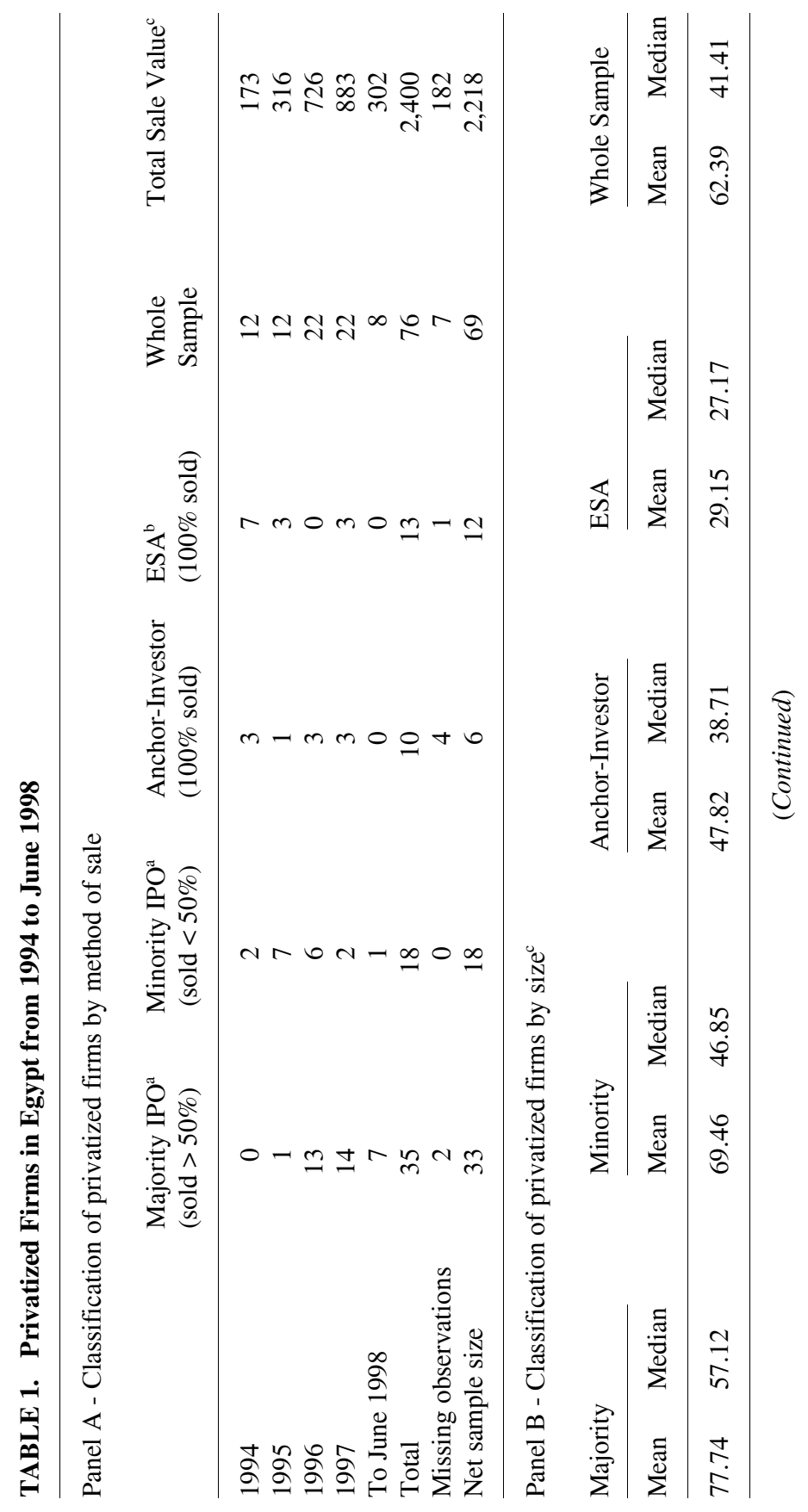




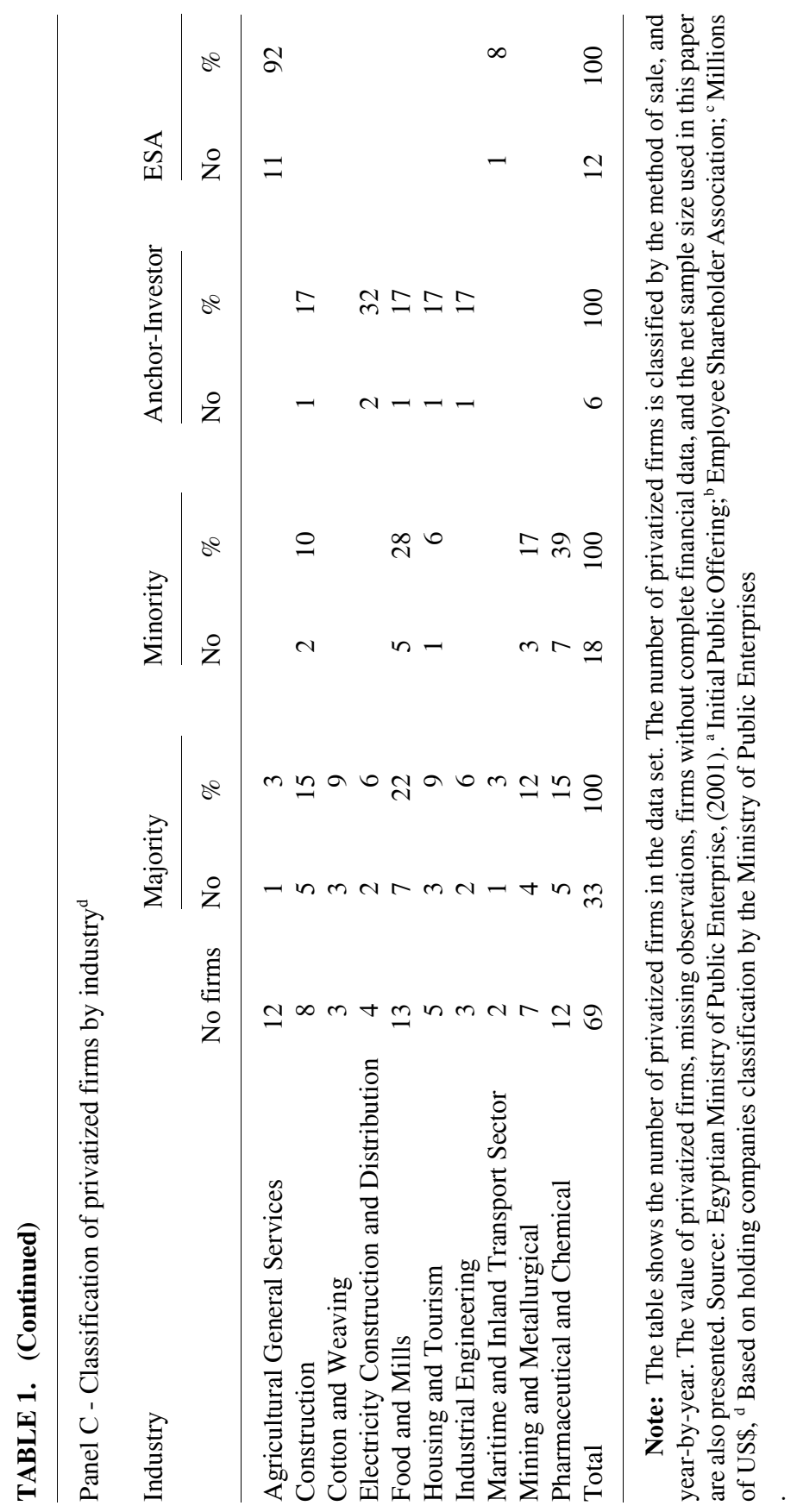


income statement that would reflect an artificial increase in net income; and the effects of levels of debt in the post-privatization period. ${ }^{7}$

\section{Operating Efficiency}

Operating Efficiency is determined by three variables: sales efficiency (SALEFF), income efficiency (INEFF), and asset turnover (AT), which refer to sales per employee, EBIT per employee, and sales to assets, respectively.

\section{Capital Expenditures}

Capital Expenditures are measured by three variables: real capital expenditures (CE), capital expenditures to sales (CESA) and capital expenditures to total assets (CETA) ${ }^{8}$ The first ratio is calculated using the normalization method after deflating the data for inflation, while the latter ratios refer to capital expenditures to sales and capital expenditures to total assets, respectively.

\section{Output}

Output is proxied by real sales (SAL) that are computed using the normalization method after deflating sales for inflation.

\section{Employment}

Employment is measured as the total number of employees (EMPL).

Leverage

Leverage is computed as total debt divided by total assets (TDTA).

\section{Dividends}

Dividends are proxied by the payout ratio (PAYOUT), which refers to cash dividends divided by net profit after tax.

Risk

Risk reflects the ability of the firm to meet its financial obligations- that is, the number of times the firm is able to cover its payable interest from

7. In any case, results using net income are found similar to the results using earnings before interest, tax, and extraordinary items.

8. Since firms do not report figures of capital expenditures in their financial statements, this variable is calculated as the difference in the sum of fixed assets and projects under progress between year $t$ and year $t-1$. 
its profit before tax and interest. Since greater coverage reduces financial risk, an increase in this ratio is expected following privatization. Financial risk is proxied by the paid interest as a percentage of EBIT. ${ }^{9}$

For each individual firm, the mean performance is calculated prior to and after privatization. ${ }^{10}$ The Wilcoxon signed-rank test is used to test for significant changes in medians, and the proportion test is employed to determine whether the proportion $(P)$ of firms experiencing changes in a given direction is greater than would be expected by chance, typically testing whether $P=0.5 .{ }^{11}$

To compare the performance change of each sub-sample group, according to the new ownership structure, the data are adjusted to ensure that such comparison is valid. The accounting performance measure for each group of firms is calculated as:

$$
R P C_{i}=\left(P_{i, t}-P_{i, t-1}\right) / P_{i, t-1}
$$

where $R P C_{i}$ is the relative performance change and $P_{i, t}$ and $P_{i, t-1}$ are the mean performances for the post- and pre-privatization periods, respectively.

After determining for each variable and each individual firm, the

9. If the paid interest is zero, the outcome of time-interest earnings would yield infinity. Since the sample size contains many cases where paid interest is zero, it is sensible to consider paid interest as a percentage of EBIT in order to avoid losing observations; hence, this ratio is calculated by dividing interest payable by earnings before interest and tax.

10. The accounting performance measures are calculated using raw data and market-adjusted data. The latter is calculated to isolate the effects of privatization from the impact of general economic conditions. The market-adjusted measure of a given firm is the difference between its accounting performance measure and the market-median accounting performance measure. The market proxies are calculated for a sample of firms, which were not privatized; they are available on the Kompass database. This rich source of financial information displays the financial statistics of respective Egyptian firms in a consistent manner-selected items are on a comparable basis. The unadjusted and market-adjusted measures are list for the whole sample only. For the sub-sample comparison, only the unadjusted results are reported for the sake of saving space. However, results are similar using unadjusted or market-adjusted performance measures.

11. The t test was used to test for significant changes in means, but because the test for normality is rejected for most variable values, this would violate one of the important assumptions underlying the $t$ test. Only the non-parametric results are reported, given that Barber and Lyon (1996), among others, document that the non-parametric Wilcoxon test statistics are uniformly more powerful than parametric t-statistics. 


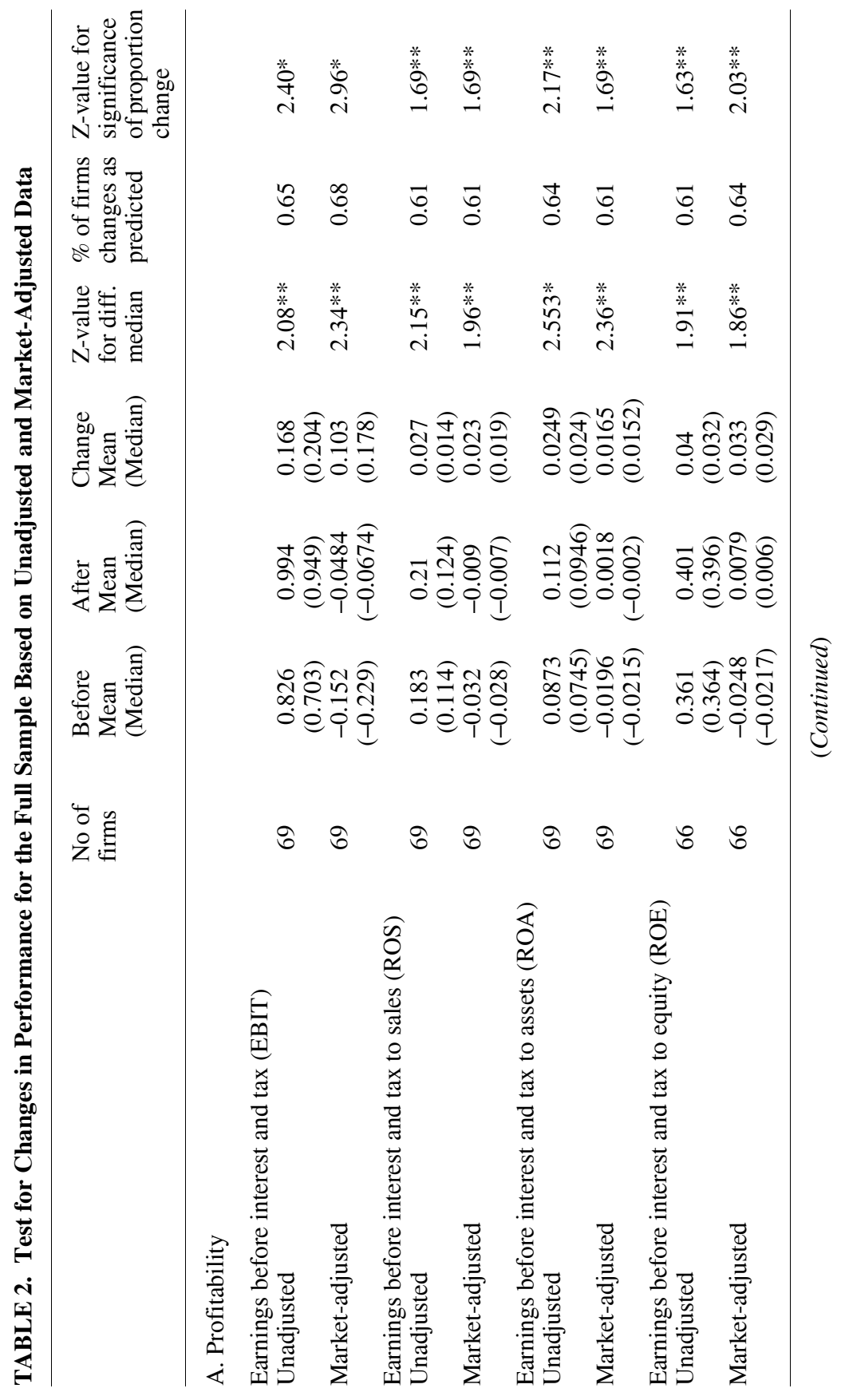




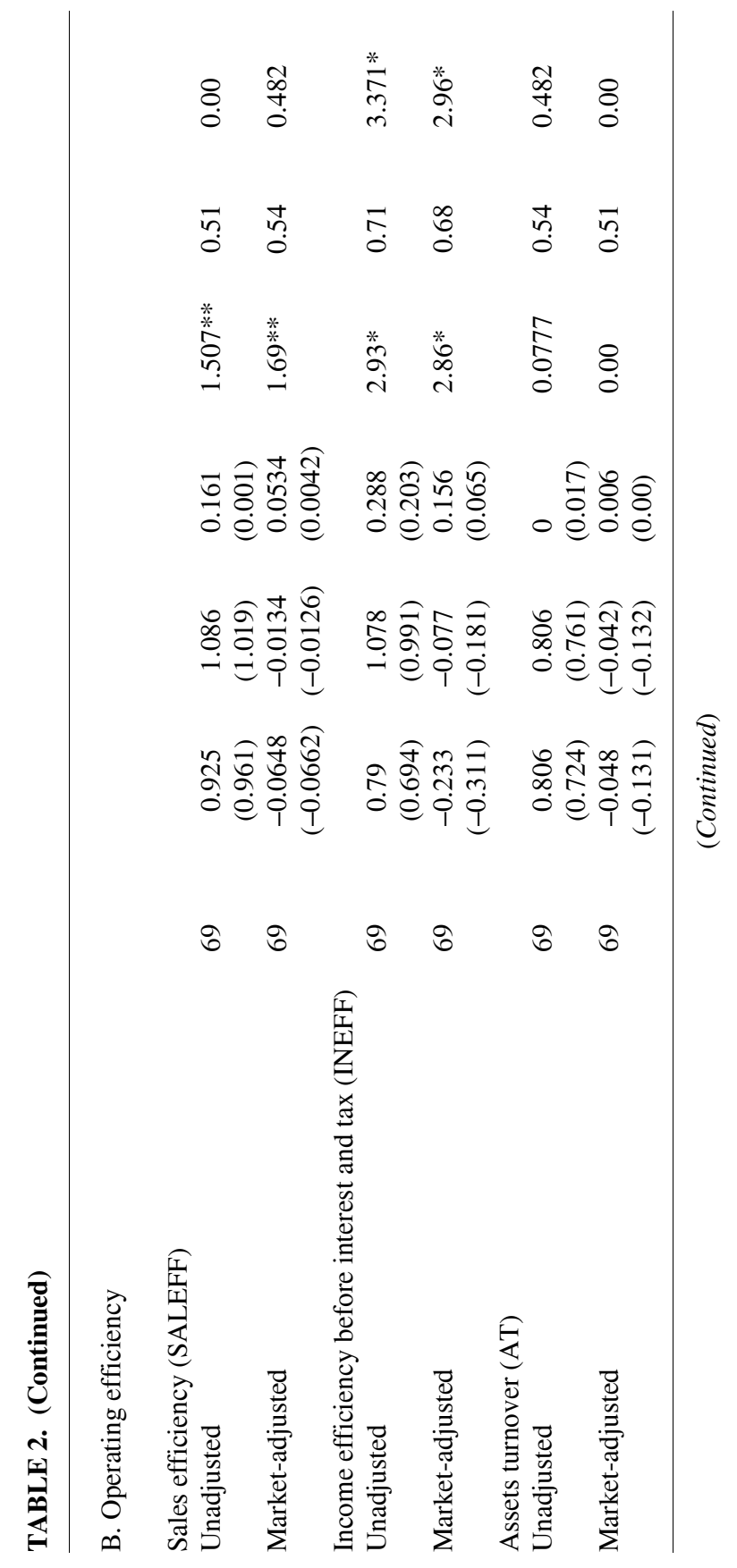




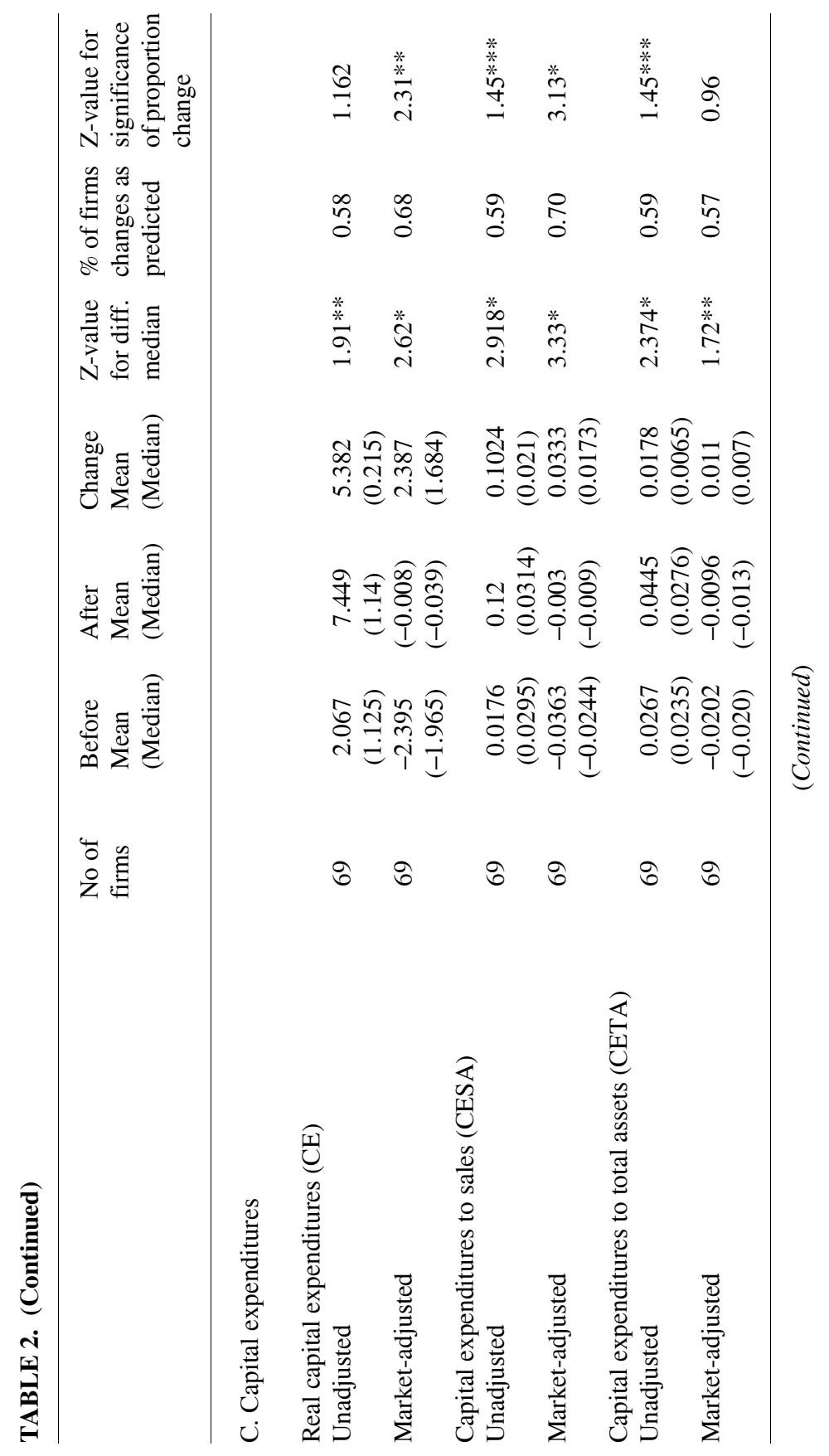




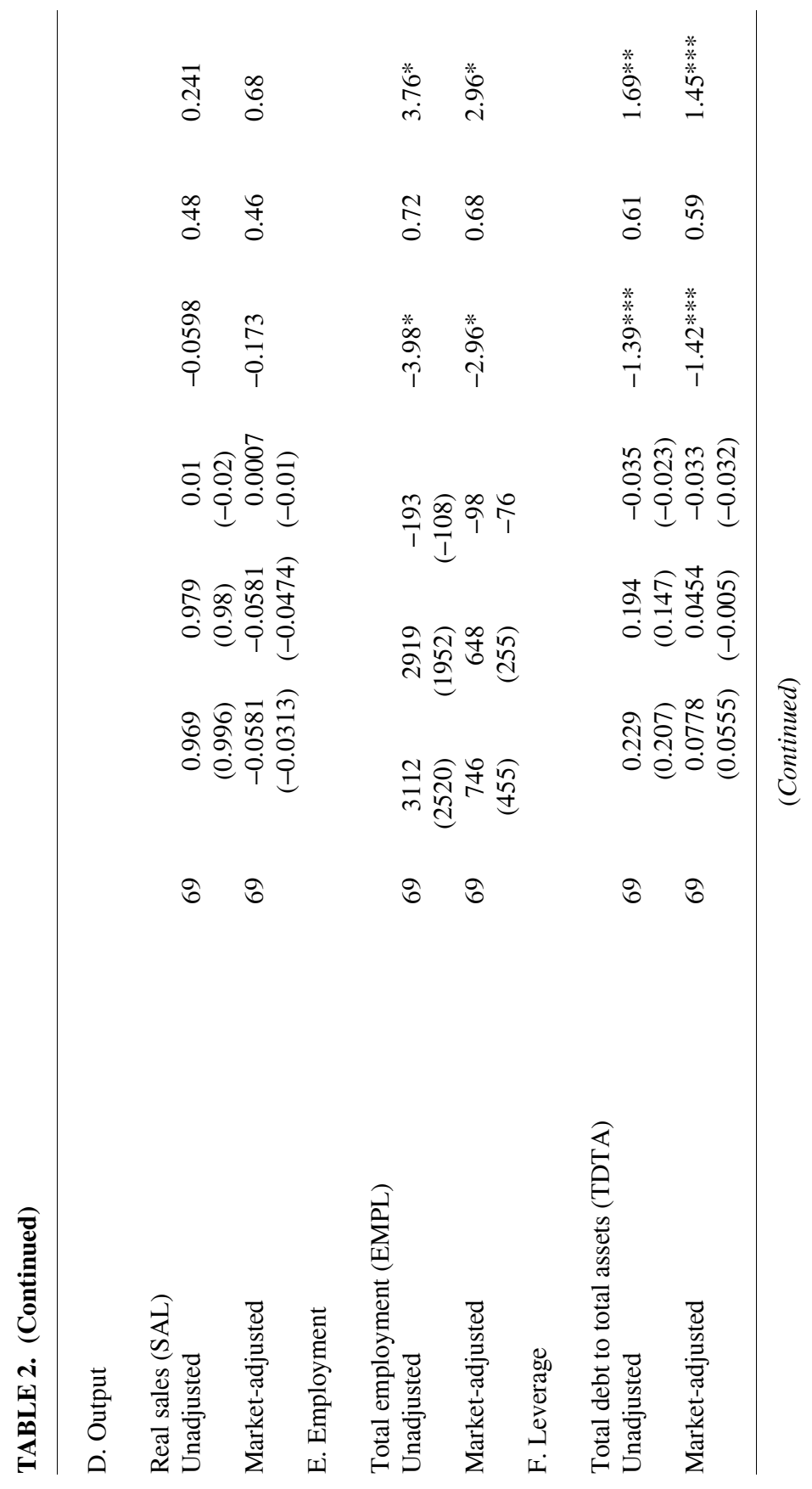




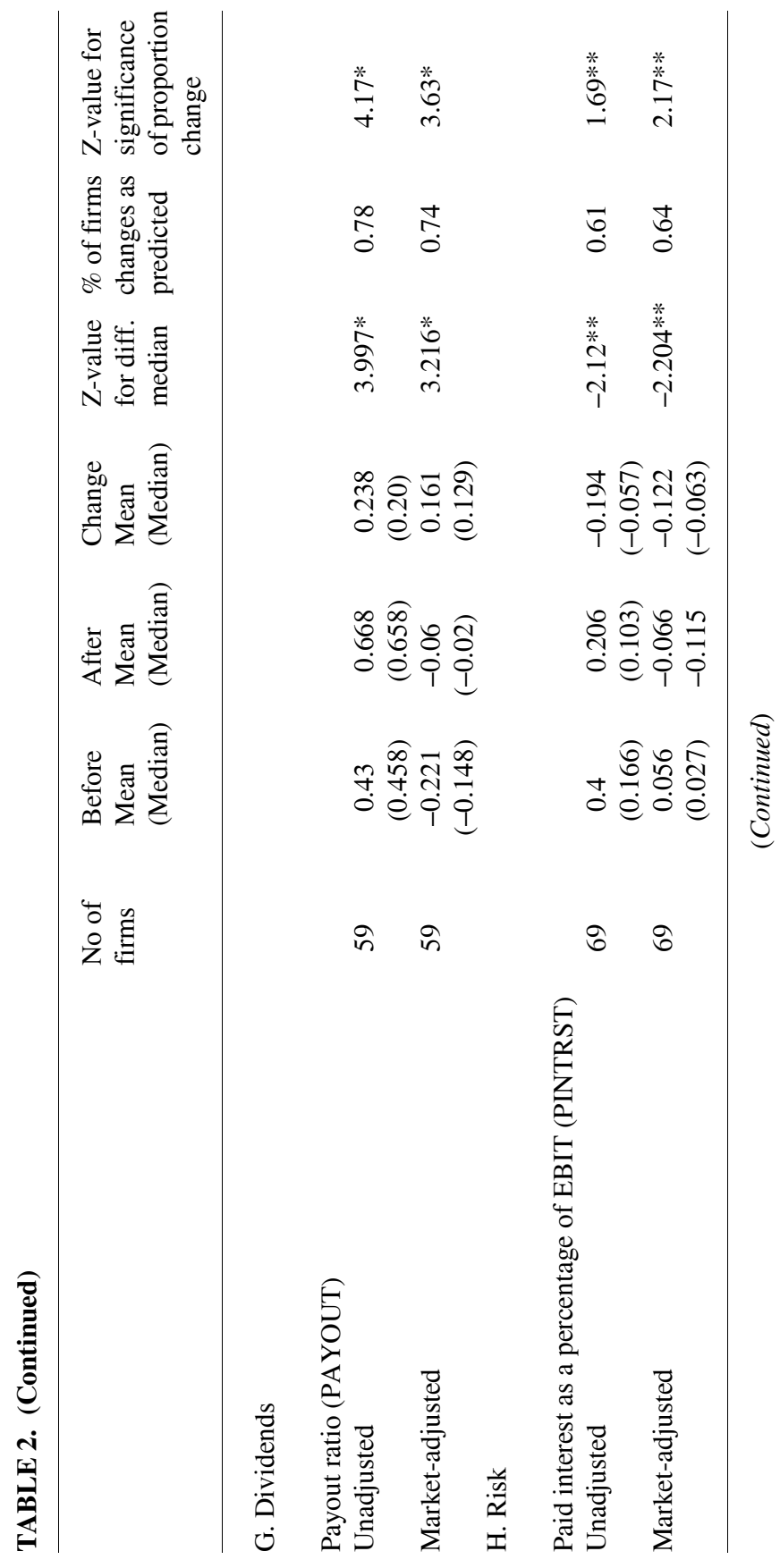




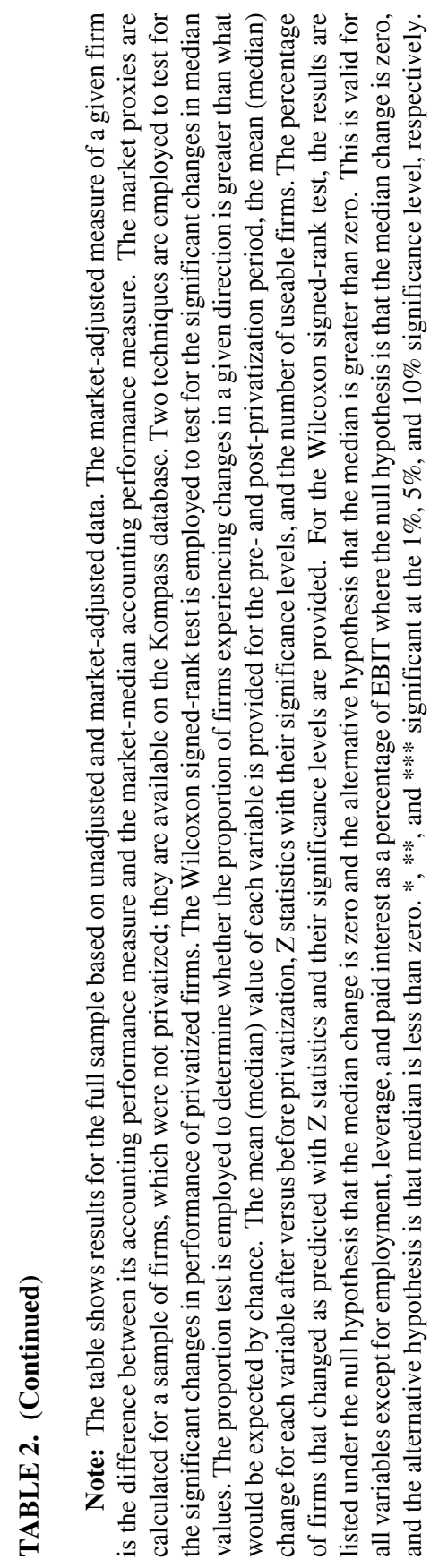




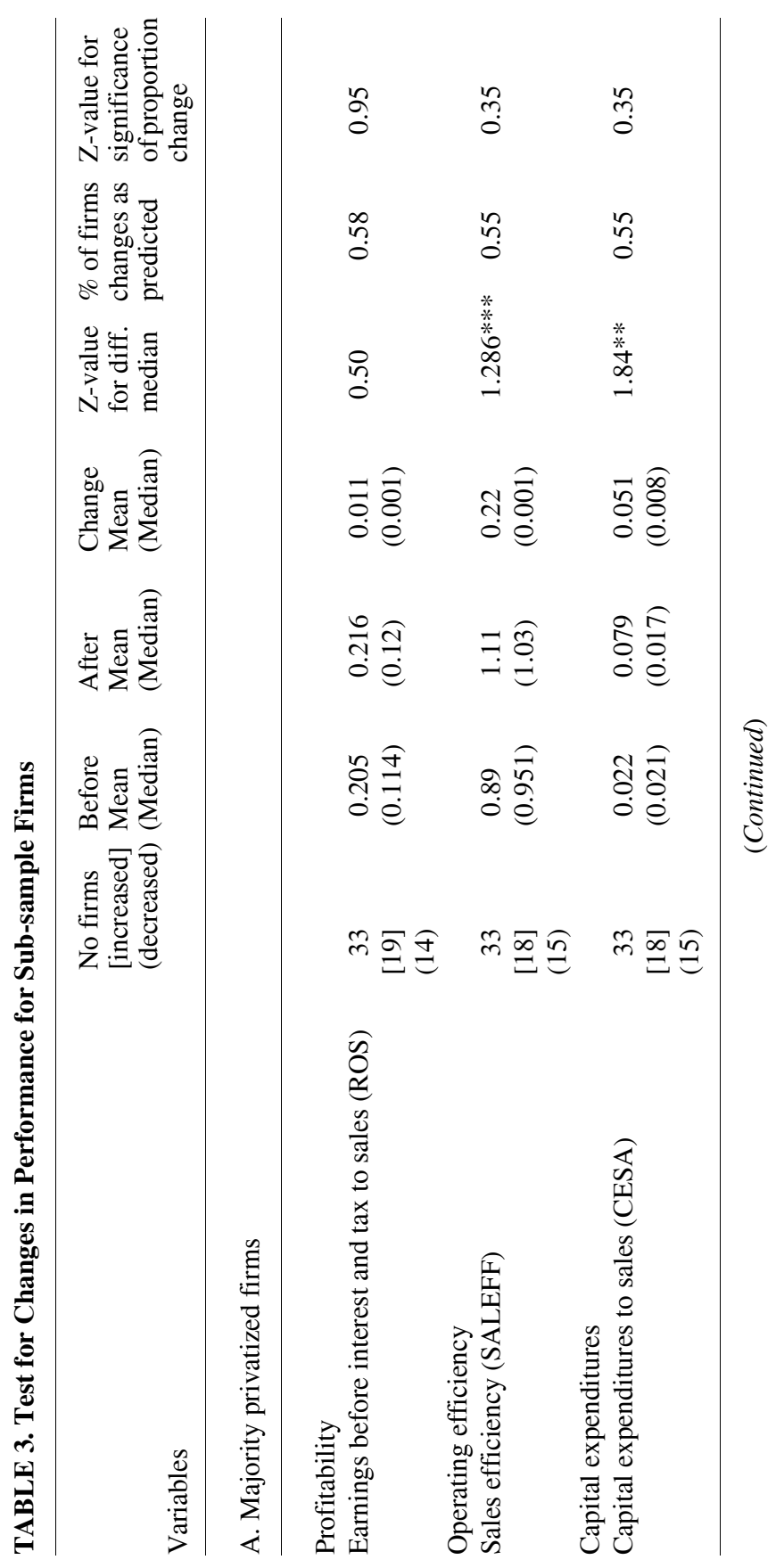




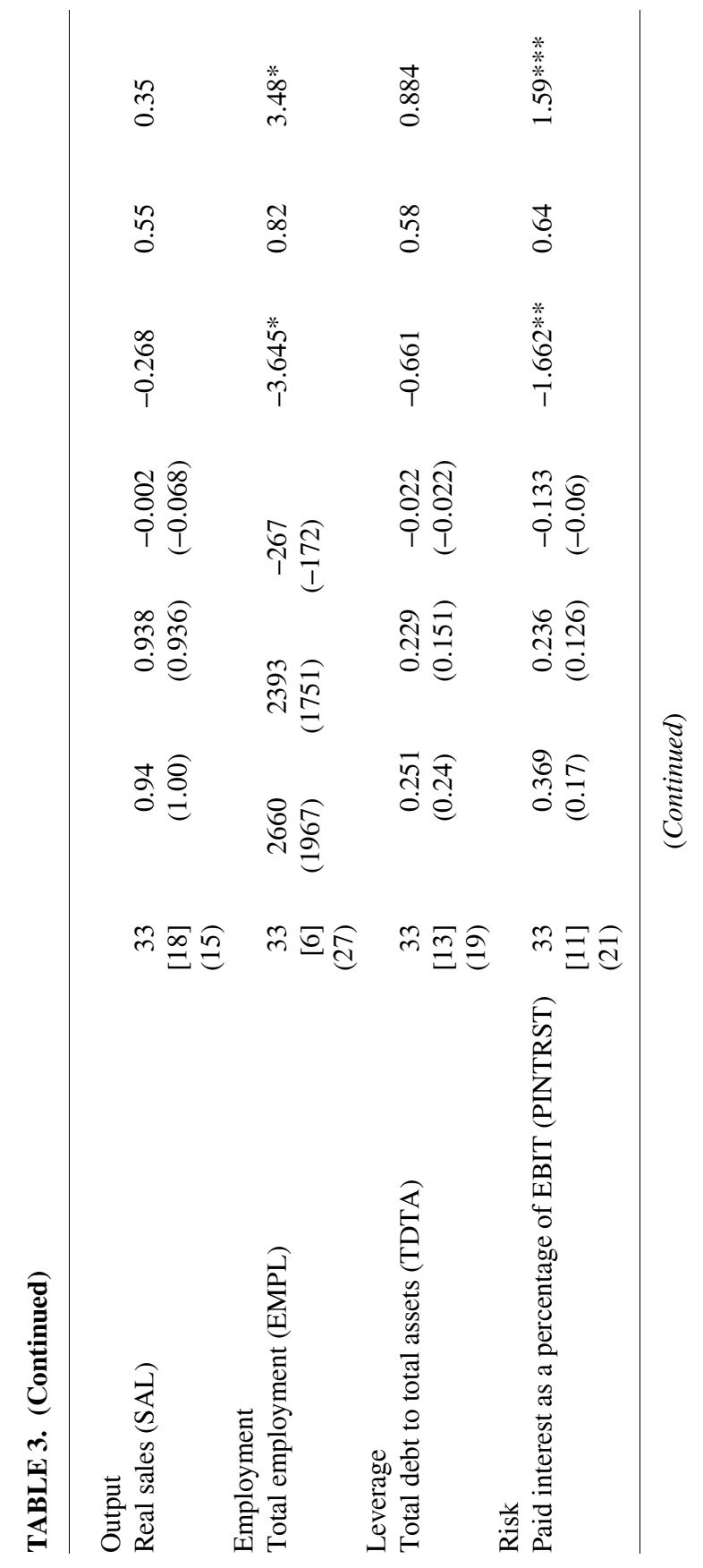




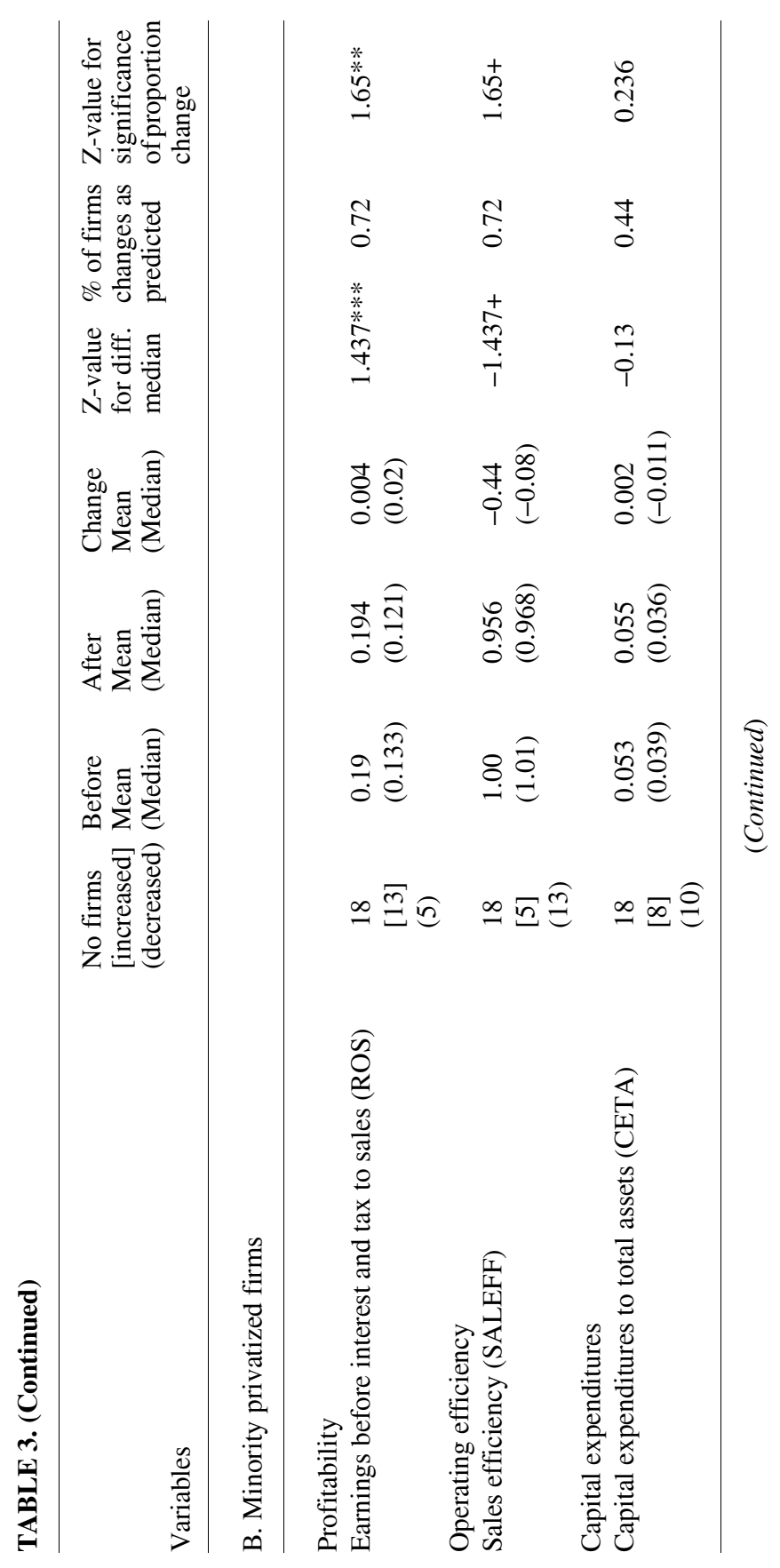




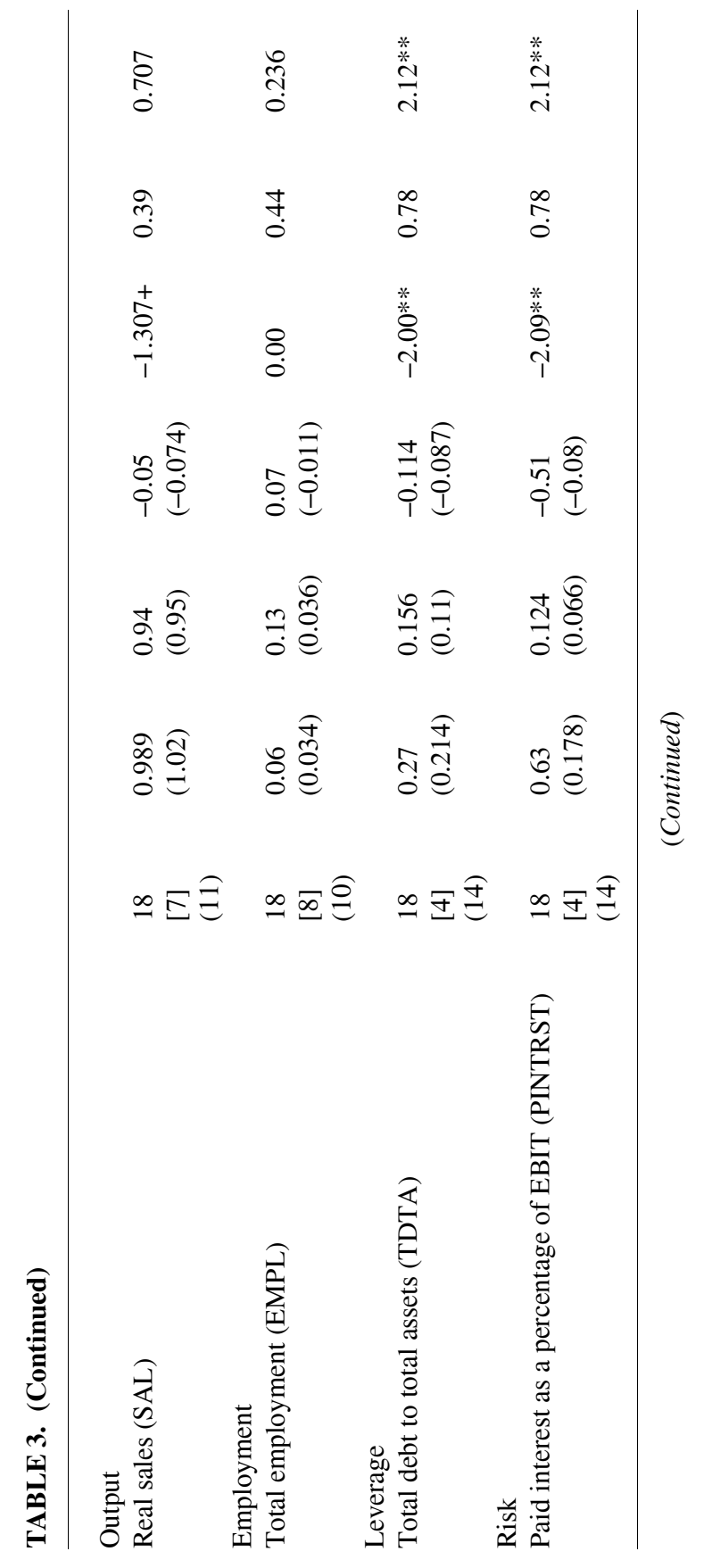




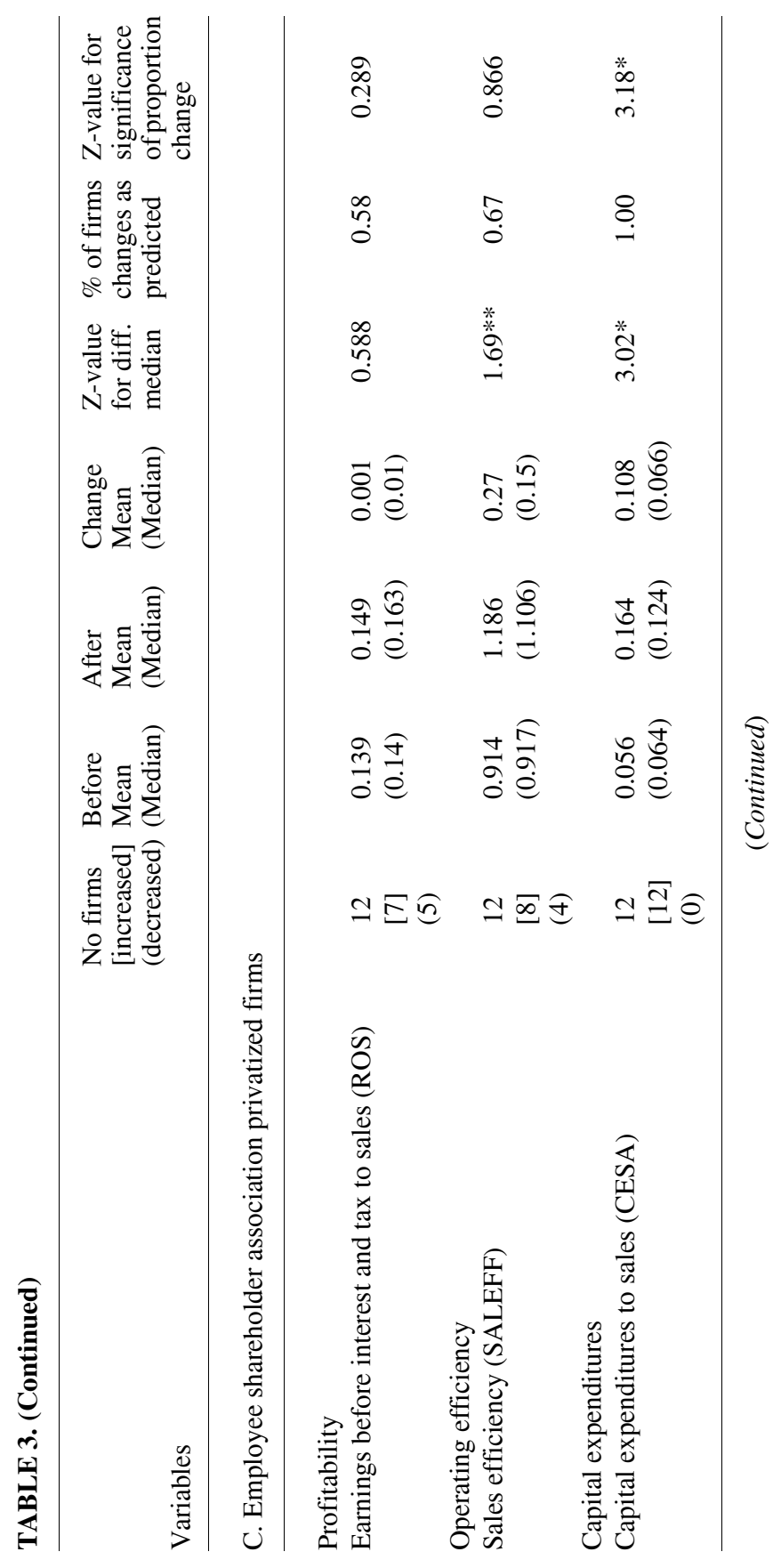




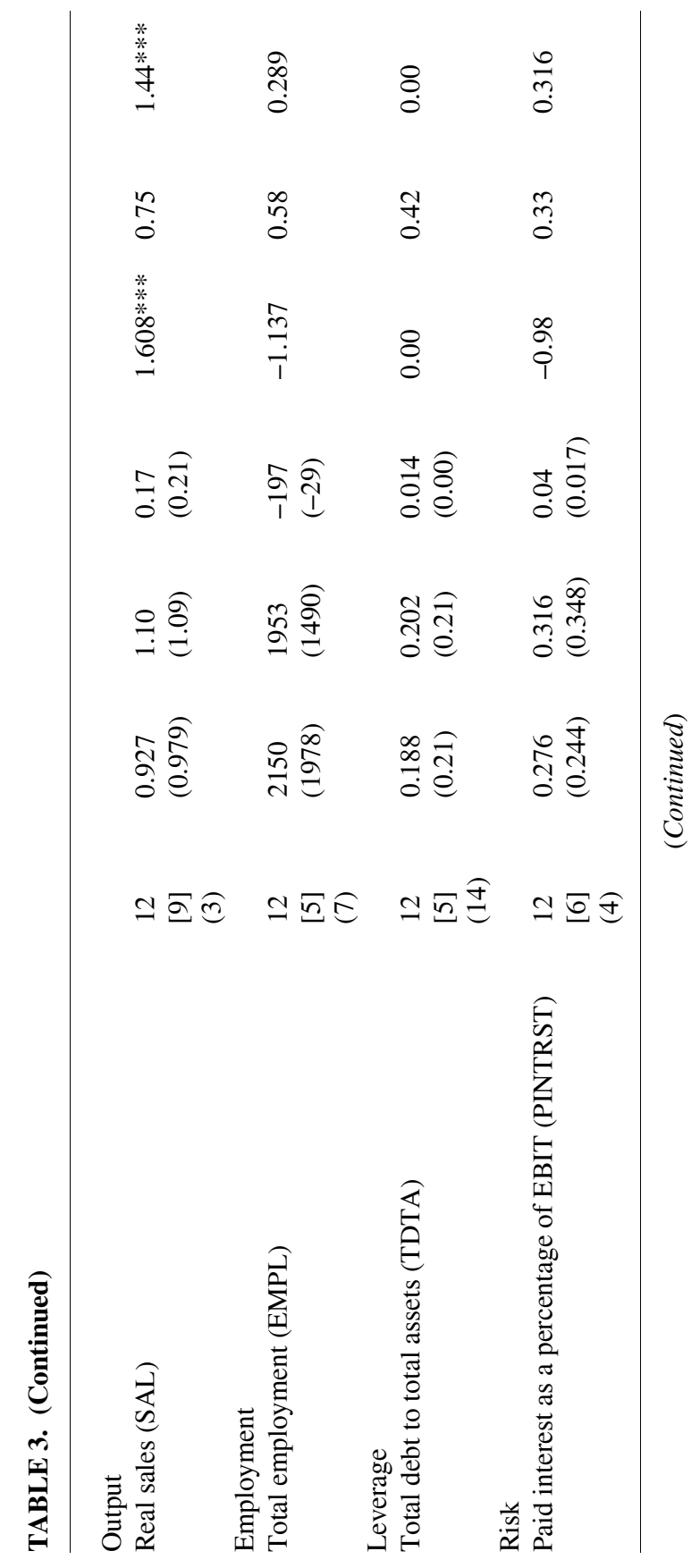




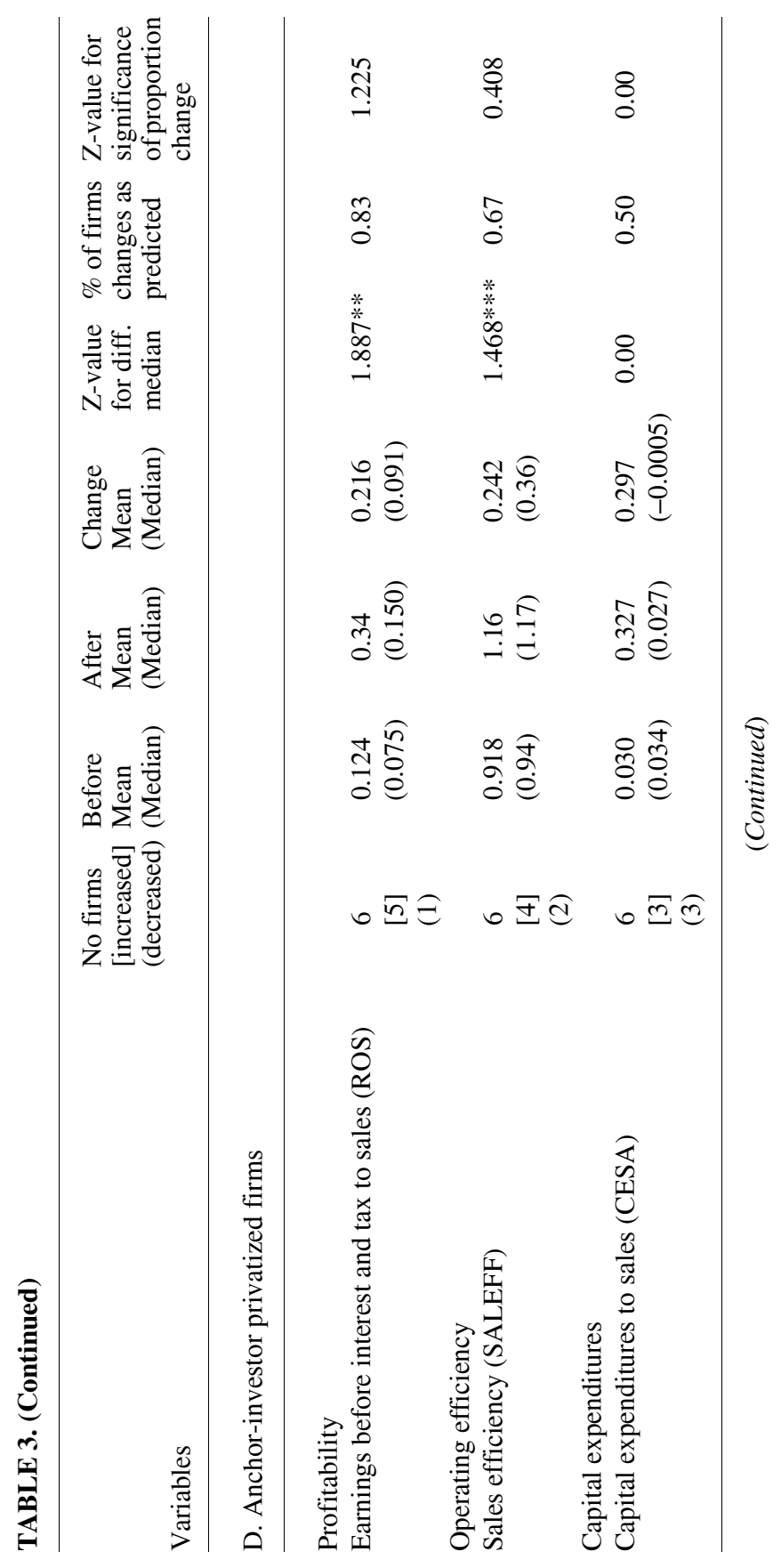




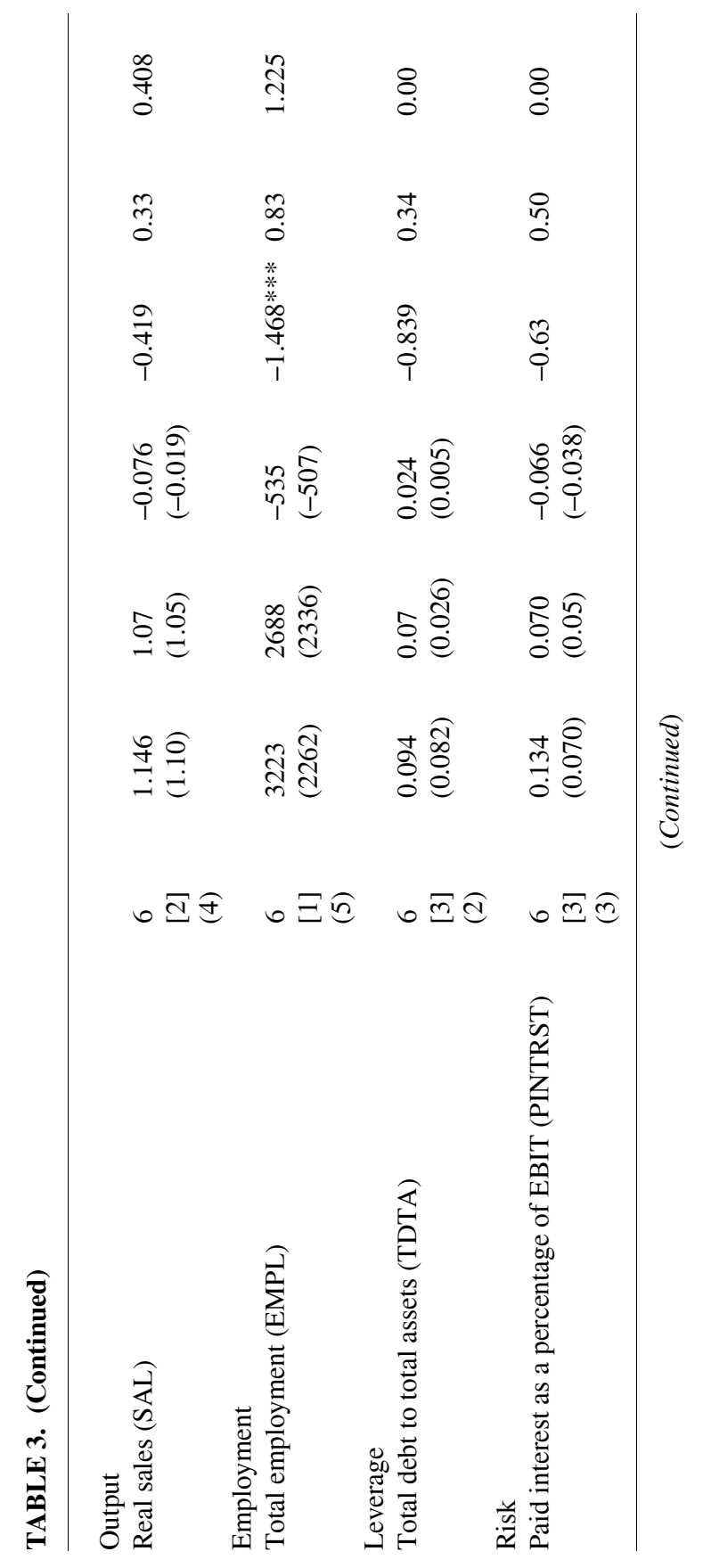




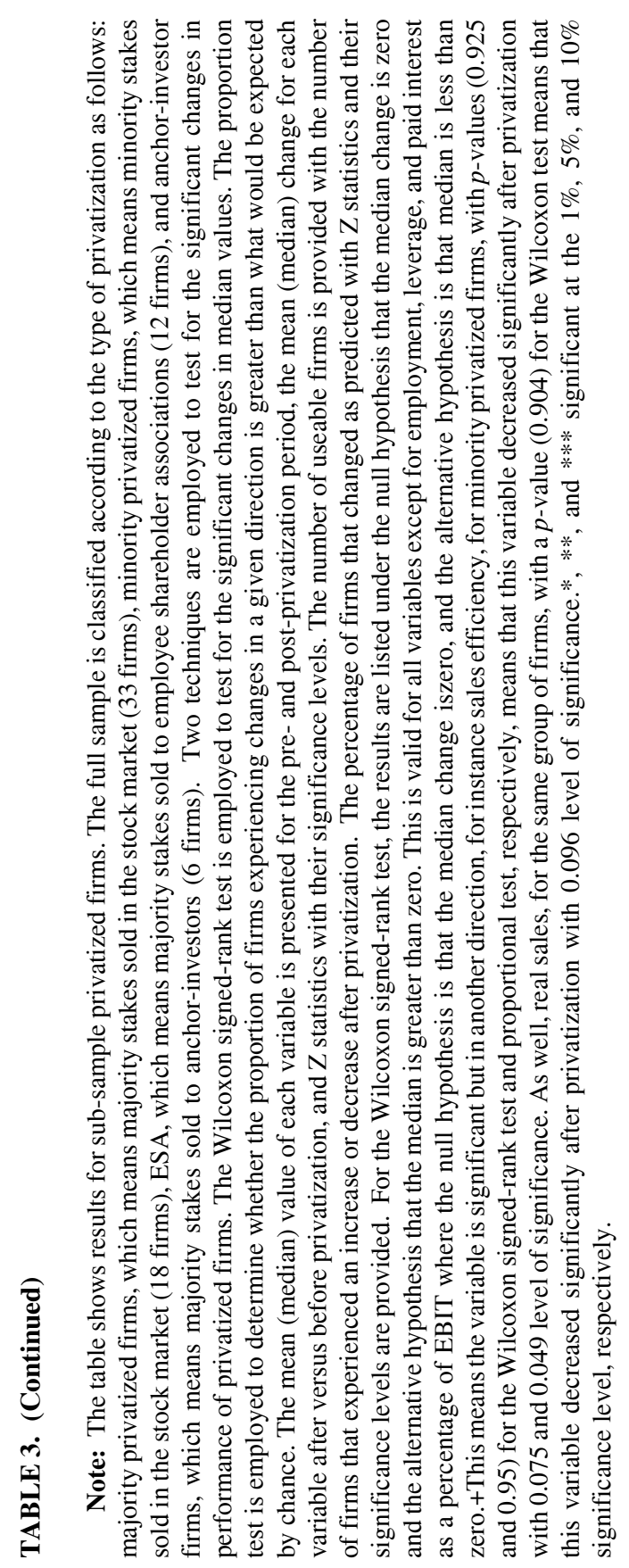


Mann-Whitney testis employed to determine if there is a significant difference between the medians of the performance measures of each pair of groups. ${ }^{12}$

\section{Empirical Analysis and Findings}

This section presents the empirical findings of the performance changes in variables described in the previous section. The analysis is based on the results of the Wilcoxon signed-rank test and the proportion test. The analysis considers the full sample of 69 privatized firms (table 2). Performance change results are also presented for each sub-sample according to the type of privatization: majority IPO, minority IPO, ESA, or anchor-investor (table 3). ${ }^{13}$ The Mann-Whitney test is used to determine whether each group of firms experiences significant changes in the values of the variables examined compared to the other groups

\section{A. Profitability}

All profitability ratios improve significantly after divestiture; see table 2. The market-adjusted mean (median) EBIT, ROS, ROA, and ROE jump from $-0.15(-0.23),-0.032(-0.028),-0.02(-0.022)$, and -0.025 $(-0.022)$ to $-0.048(-0.067),-0.009(-0.007), 0.002(-0.002)$, and 0.008 (0.006); respectively. Both statistical tests pass the critical values of significance at the one and five percent level. The increase in all profitability measures is equally significant as low as 61 percent and as high as 68 percent of the sample firms.

In the sub-sample results in table 3 , it is evident that profitability ratios exhibit improvement, but the significant changes in performance vary across ownership types. Further the sub-sample comparison results in table 4 provide some evidence that the anchor-investor group has significantly higher profitability ratios compared with the majority and minority groups, and the ESA group shows better performance compared to the majority and minority groups although the statistical

12. Results reported for the Mann-Whitney test are corrected for ties.

13. For the sake of space, the results are reported for some proxies that represent the most important measures. However, the test results for all performance measures of each group of firms tend to be qualitatively similar to those reported for the full sample. 


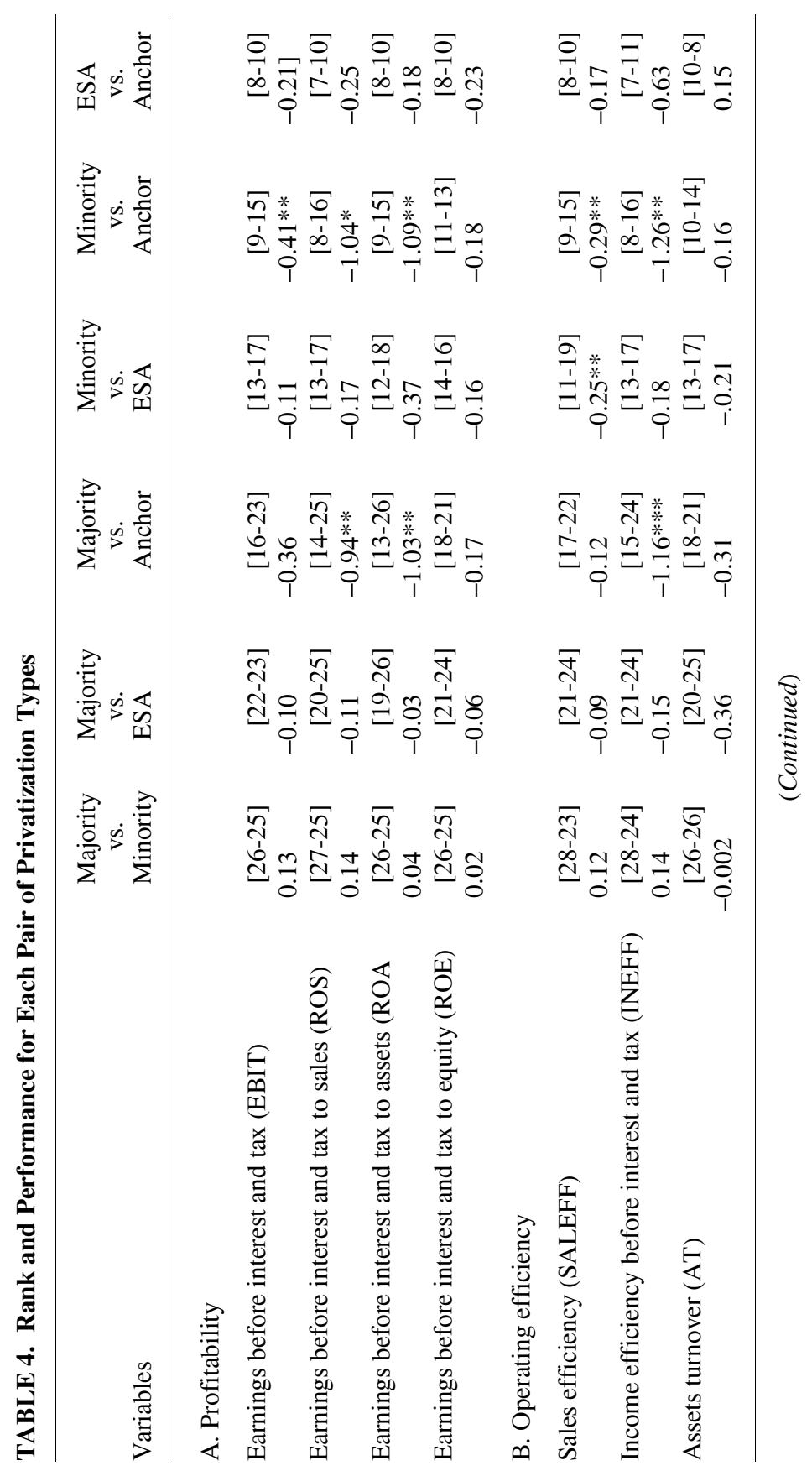




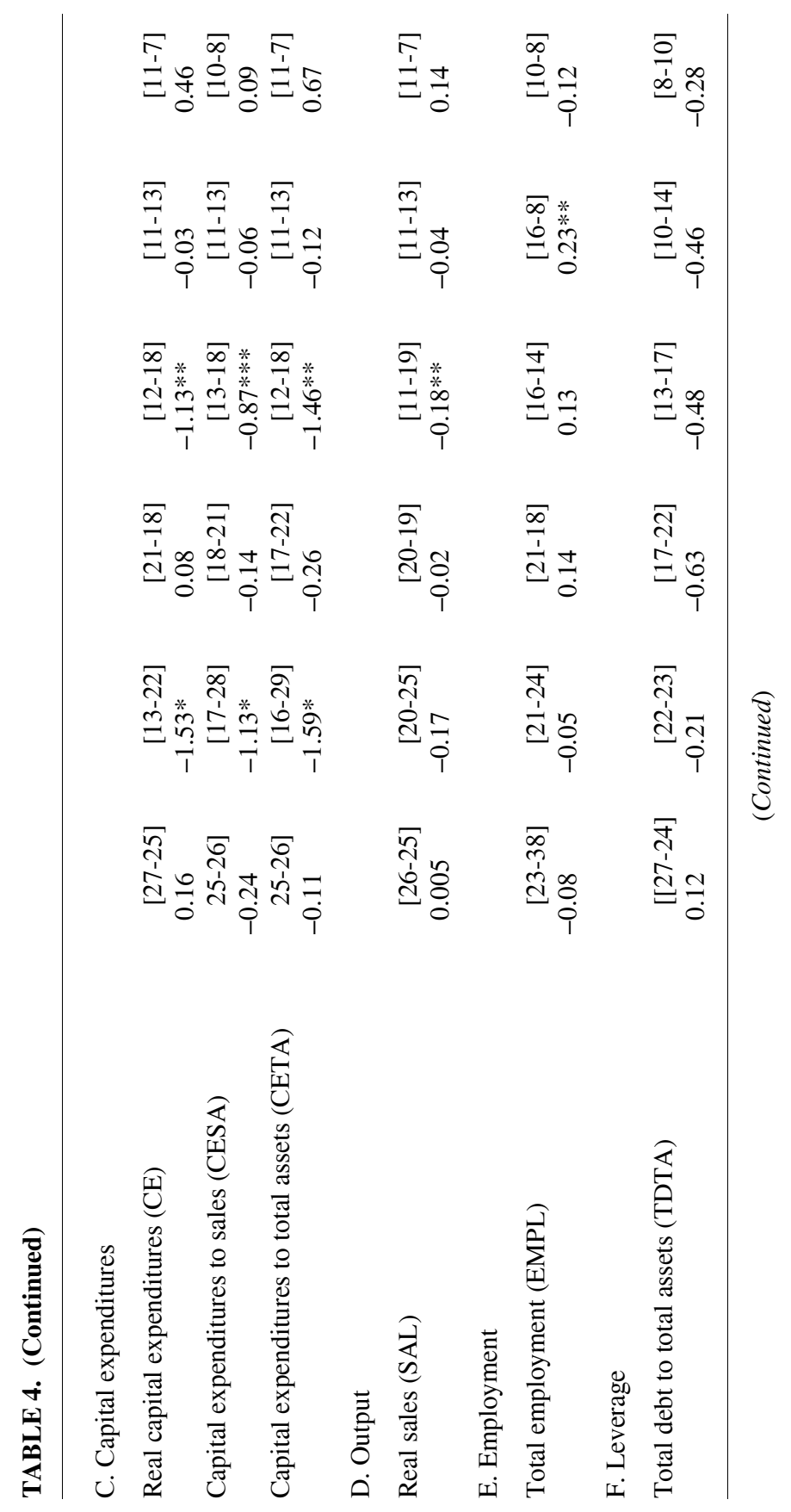




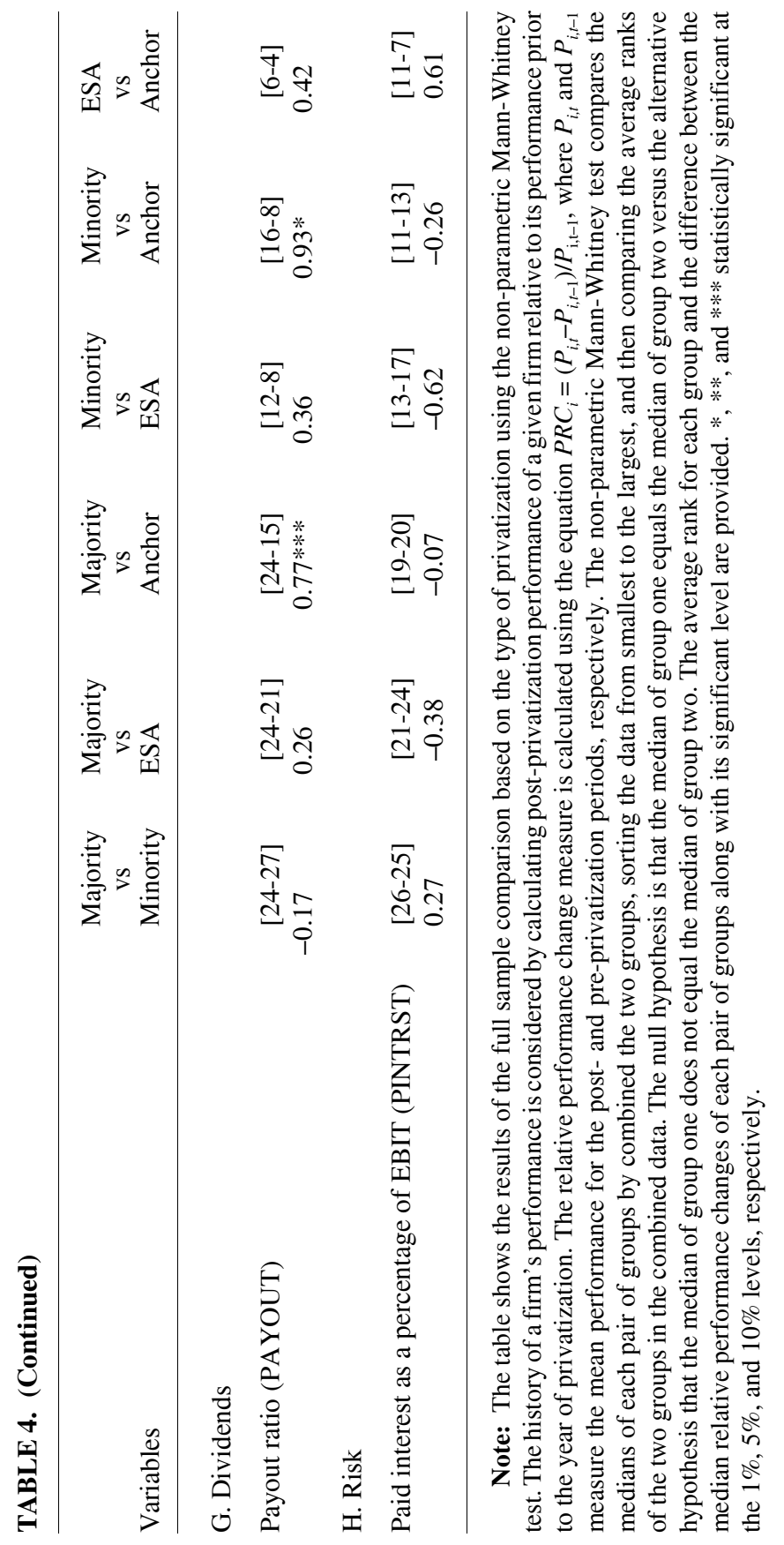


test is not significant at any level. However, no significant difference in performance is found between majority IPO - minority IPO, and ESA anchor-investor sub-samples. ${ }^{14}$

\section{B. Operating Efficiency}

The SALEFF and INEEF ratios show significant increases following privatization at the five and one percent levels, respectively. The mean (median) market-adjusted values of SALEFF and INEFF increase from $-0.065(-0.066)$ and $-0.23(-0.31)$ of the year 0 level during the pre-privatization period to $-0.0134(-0.0126)$ and $-0.077(-0.18)$ of the year 0 level during the post-privatization period, respectively. Such increases are achieved by 51 percent of the sample firms for the first ratio and 68 percent for the latter one. However, using market-adjusted and unadjusted results, the AT ratio shows an insignificant change. Such findings support the argument that any improvement in earnings is mainly due to cutting costs and expenses and/or reducing the level of employment rather than increasing revenues from sales.

All sub-samples demonstrate significant improvements in all operating efficiency ratios, except for the AT ratio. However, the minority group shows a significant decrease in SALEFF after privatization at the 10 percent level and 72 percent of the sample firms experience such a decrease.

Nevertheless, results indicate that not all sub-samples experience identical performance. Again, the evidence shows that the anchor-investor privatized firms group performs better compared to other groups, in particular minority and majority IPOs. Moreover, the ESA privatized firms group comes second in terms of performance- and is significant in certain cases. It can also be observed that the minority privatized firms group performs relatively worse when compared to the other groups.

Privatized firms, as a whole, show significant improvements in both profitability and operating efficiency after divestiture. Equally important is that anchor-investor firms perform better than all other privatization classifications, followed by the ESA group. Such findings are consistent

14. The Mann-Whitney test was also used to test for the difference in medians between each individual group and other groups combined. More precisely, it was used to test whether the performance change in any given type of privatized firm is different from others considered jointly. The results support the earlier findings that anchor-investor and ESA groups perform better than other groups. 
with Shleifer and Vishny (1997) and Claessens et al. (1997), who argue that concentrated ownership results in better monitoring of managers and increased stock value. As such, it might be understandable that concentrating ownership in the hands of a small group such as anchor-investors would yield higher profits and better performance. However, the most surprising result is that the ESA privatized-firm group seems to outperform other types of privatization except anchor-investors. In this context, this result appears to be consistent with Earle (1998), who finds a positive relationship between firm performance and both managerial and non-managerial employee ownership, and with Boubakri and Cosset's (1998) proposition that employee stock ownership plans (ESOPs) favor employees' support for a privatization policy and performance improvements. At the same time, these results contradict the argument of Boycko et al. (1996), who predict that workers make poor stockholder/monitors. Additionally, the relatively poor performance of partially privatized firms (minority) compared with other groups might be due to the fact that, in partial privatization the government would still have a hand in controlling management, thus hindering management performance and making firms less efficient.

\section{Capital Expenditures}

Both unadjusted and market-adjusted results show significant increases in all ratios of capital expenditures (i.e., CE, CESA, and CATA) at conventional significance levels.

Using both the Wilcoxon signed-rank test and the proportion test, the results indicate that post-divestiture increases in capital expenditures are highly significant for the ESA privatized-firm group for all three variables at the one percent level. In contrast, none of these variables is significant for the minority IPO and anchor-investor privatized-firm groups, whereas the majority IPO group shows significant increases for CESA and CETA, but not for CE. On the other hand, different results are found after adjusting the data to make it comparable across subsamples. The results indicate that the ESA privatized-firm group shows significantly larger increases in capital expenditures compared with the majority and minority privatized-firm groups. However, such an increase is not significant when compared with the anchor-investor privatized-firm group. 


\section{Output}

As confirmed above, privatization leads to improvements in profitability and operating efficiency, and an increase in capital expenditures; it is also argued that privatization increases output. Surprisingly, the Wilcoxon signed-rank test and the proportion test show insignificant decreases in output following privatization in contrast to the expectation of an increase. However, this result seems to be consistent with Boycko et al.'s (1996) argument that effective privatization leads to a reduction in output since the government can no longer entice management (through subsidies) to maintain inefficiently high output levels. ${ }^{15}$

Extending the analysis to sub-samples, an insignificant change is shown for majority IPO and anchor-investor privatized groups, while a significant decrease in output is documented for the minority IPO privatized group at the ten percent level. Additionally, the ESA privatized group is the only group that shows a significant increase in output at the ten percent level. The results from sub-sample comparison confirm the same findings as the ESA privatized group shows a significantly larger increase in output compared with the minority group at the five percent level. Additionally, the ESA group performs better than the majority and anchor-investor groups, but differences are insignificant.

\section{E. Employment}

Employment is an important and critical issue in privatization because of the possibility that privatization could lead to cutting the current level of employment. There is neither a theoretical nor an empirical consensus concerning the impact of privatization on employment. The results of both the Wilcoxon signed-rank test and the proportion test show that employment decreases significantly after privatization. This significant decrease at the 1 percent level is achieved by 72 and 68 percent of the sample firms based on unadjusted and market-adjusted data, respectively. With regard to sub-samples, majority and anchor-investor privatized groups experience significant decreases at the one and ten percent levels, respectively. In contrast, minority and ESA

15. This could also be due to firms having large inventories prior to privatization, so that new management might concentrate primarily on marketing activities in favor of production activities. Since the quality of SOE products, in general, is lower than that of private competitors, it would be logical to observe an insignificant change in this variable. 
groups show insignificant decreases.

Th sub-samples comparison results show a significantly smaller decline in the level of employment of the minority privatized group compared to the majority and anchor-investor groups at both the one and five percent level of significance. The ESA group also has a smaller decline in the level of employment compared with minority and anchor-investor groups, but such differences are not significant at any level. It might be logical that the ESA privatized group does not witness a significant decrease in the level of employment because ownership is transferred to employees themselves, but it is quite interesting to note that partial privatization does not affect the level of employment either. One possible explanation is that the government wishes to show the public that it is still considering some social aspects in its privatization policy.

\section{F. Leverage}

Privatization might decrease a firm's degree of financial leverage as the cost of debt will be higher for a privatized firm compared to an SOE, given that the public sector has the advantage of paying a lower interest rate on debt. On the other hand, privatized firms have more opportunities to access equity markets -domestically and internationally (Bradley, Jarrell, and Kim, 1984). Hence, one might expect that the debt ratio would decline after privatization. This proposition is tested by computing total debt to total assets (TDTA). A significant decline in this ratio is found at the 10 percent level, and this change in capital structure is achieved by 61 and 59 percent of the sample firms based on unadjusted and market-adjusted measures, respectively. The significant change in the leverage ratio is documented for the minority IPO privatized group, while other groups do not show a significant change in their capital structure. Comparing sub-samples, the results show that the value changes in TDTA are larger for the minority privatized group compared with other groups. However, these differences are not significant at any level. Such results are consistent with Kocenda and Svejnar's (2002) findings as they document that majority state-ownership is associated with linearly declining financial leverage. The argument here is that the government might try to carry out strategic restructuring by reducing the debt ratio to be able to sell the remaining stakes of the partially privatized firms. 


\section{G. Dividends}

Megginson et al. (1994) point out that no theoretical or political argument deals with the issuance of dividends, but it might be argued that pay-outs would increase because-unlike the state-private investors generally demand dividends. Hence, an increase in dividend pay-outs is expected following privatization. ${ }^{16}$ The results from comparing preversus post-privatization periods reveal a very significant increase in the PAYOUT ratio following privatization at the one percent level. Seventy-eight and seventy-four percent of the sample firms achieve such significant positive changes using unadjusted and market-adjusted measures, respectively. As far as sub-sample performance is concerned, results (not reported here) indicate a strong increase in PAYOUT for majority and minority privatization groups at the one percent level for both statistical tests. However, no significant difference between the two groups is discerned. ${ }^{17}$

\section{H. Risk}

Financial risk reflects the ability of firms to face their financial obligations; therefore as firms move from public to private ownership, it is expected that they will manage their debt in a more efficient manner- that is, they will try to minimize their cost of debt. Given this proposition, one might expect an increase in the ability of firms to cover their interest payable following privatization. However, as explained in Section 3, for calculation reasons, paid interest is computed as a percentage of EBIT as a proxy for financial risk. Therefore, a decrease in this ratio for firms following privatization is expected. The market-adjusted results indicate a significant decline in this ratio at the 5 percent level, and this is achieved by 64 percent of the sample firms. As for sub-samples, this significant decline no longer exists for ESA and anchor-investor groups, while it is significant for majority and

16. Given that some firms experienced losses in the pre-privatization period and were financially unable to distribute dividends, they are excluded from the analysis.

17. Although the statistical test results for ESA and anchor-investor groups are reported, the number of observations is too small to allow for comparison. Excluding these two groups is based on the facts that (i) some data on dividends after privatization are missing, in particular for the anchor-investor group, and (ii) some firms witnessed losses prior to privatization and did not pay dividends. To include these cases in the analysis would make the comparison meaningless and misleading. 
minority groups. The results from the sub-sample comparison suggest that there is no significant difference in value changes of financial risk between each pair of sub-samples at any level.

\section{Further Discussion}

It might be important to shed light on some points related to firm characteristics. The performance differences across sub-samples might be questioned if the privatization methods of sale were not random; in which case a selection bias problem could exist. Consequently, it is important to look at two important factors related to firm characteristics: industry and size. As for industry, the changes in the economic system in Egypt might have had a different impact on the various sectors, thus on each firm operating in each sector. Looking at the sample firms (table 1), apart from the ESA group, it seems that the government does not differentiate between specific methods of sale according to a firm's industry classification. To capture industry effects the Kruskal-Willis test is employed to determine whether significant differences exist among privatized firms-classified by industry. Although sample sizes are too small in many industries for significance tests, the results (not reported here) for larger samples document insignificant differences.

As for size, one could argue that smaller firms grow faster than larger firms, and thus the differences in performance across sub-samples might be due to the size effect. Panel B of table 1 indicates that size differs across the four classified groups of firms. So, it seems that the government usually sells smaller firms to ESAs. However, simple regressions are employed using profitability and operating efficiency measures as dependent variables and size as an independent variable. A dummy variable is used as a proxy for the size that refers to the median size of the sample firms, which takes one if the firm is above the median and zero other wise. The results (not reported here) indicate that the coefficient is negative, which means that smaller firms might perform somewhat better than larger firms although the difference is statistically insignificant. ${ }^{18}$ The conclusion from this discussion supports the previous findings that ownership structure does matter, regardless of industry and size effects.

18. The non-parametric Mann-Whitney test is employ and the results show no significant differences between smaller and larger firms. 


\section{Conclusions}

This study analyzes and evaluates the financial and operating performance of newly privatized Egyptian firms between 1994 and 1998 and tests whether their performance differs according to their post-privatization ownership structure. For the full sample, significant increases in profitability, operating efficiency, capital expenditures, and dividends are found, while a significant decline in leverage is documented. Such empirical findings seem to be consistent with those documented by benchmark studies; e.g., Megginson et al. (1994), Boubakri and Cosset (1998) and D'Souza and Megginson (1999). In contrast to the benchmark studies, this paper finds an insignificant change in output. With regard to the level of employment, a highly significant decrease is documented following privatization, which contradicts Megginson et al. (1994) and Boubakri and Cosset (1998) but is consistent with LaPorta and Lopez-de-Silanes (1997) and Ramamurti (1997). Moreover, a significant decrease in financial risk following privatization is found. Comparing sub-samples-partitioned by ownership structure- the results indicate that the performance changes in all accounting measures aforementioned are pervasive.

As for the effects of post-privatization ownership structure on firm performance, the results indicate no significant difference in performance changes between majority- and minority-firms or between anchor-investor and ESA firms using most accounting performance measures. However, a significant difference in most major variables such as profitability, operating efficiency, and output is found in the performance changes between the anchor-investor and ESA firm groups, and majority IPO and minority IPO firm groups. Moreover, the performance change of the anchor-investor group appears to be similar to that of the ESA group. Both groups of firms obviously improve their efficiency and profitability, but with different strategies: (i) anchor-investor firms by cutting cost (significantly lower employment, no increase in capital expenditures) while maintaining the same level of output, and (ii) ESA firms with no or less cost cutting (no significant decrease in employment), but additional capital expenditures (highly significant) and a significant increase in output. It seems that ESA firms concentrate more on growth since they are not willing to reduce costs through cutting the level of employees, given that the employees themselves are the owners of these firms, while the anchor-investor firms can easily cut cost by reducing the employment level. Moreover, 
the finding that the dividend payout ratio significantly increased in all except ESA and anchor-investor firms might indicate that the owners of ESA and anchor-investor firms are long-term investors, whereas the new owners of firms privatized via the stock market are (probably) not. This view can be supported by the fact that anchor-investor firms do not face any market pressures from shareholders as the owners and managers of these firms are the same. As for ESA firms, the sale of these firms is carried out with repayments over eight to ten years. The shares remain in the custody of the holding companies and are released to the employees only when payments equal to the shares held are made. However, the payments are made through net profit, which is why dividends are not paid.

Taking into account all these results, the evidence suggests that both the full sample as well as the sub-samples show significant improvement following privatization. Additionally, the level of performance differs according to the type of new ownership structure. However, the most significant and important observation is that partial privatization does not work as well as full privatization. Moreover, firms with concentrated and homogeneous ownership (anchor-investor and ESA) show superior performance changes relative to firms with more dispersed ownership structures. However, an important caveat to the results is that one of the sub-samples (anchor-investors) is particularly small in size, a limitation that might affect the validity of these findings.

In light of the results of this study, certain policy implications could be drawn. For one, the government should not remain a shareholder in privatized firms if it desires to improve the performance of privatized firms by preventing state interference in management. Equally important, an effective mechanism for legal protection of minority ownership rights is needed in order to have a strong and transparent corporate governance system, which would have a positive impact on firm performance.

\section{References}

Agrawal, A. and Mandelker, G.N. 1987. Managerial incentives and corporate investment and financing decisions. Journal of Finance 42(4): 823-37.

Anderson, C.W.; Makhija, A.K.; and Spiro, M.H. 1997. Foreign ownership in the privatization process: Empirical evidence from Czech Privatization. Working paper. Pittsburgh: University of Pittsburgh. 
Baker, S. and Weiner, E. 1992. Latin America: The big move to financial markets. Business Week 15 (June): 50-55.

Barber, B. and Lyon, J. 1996. Detecting abnormal operating performance: The empirical power and specification of test statistics. Journal of Financial Economics 41 (3): 359-399.

Barberies, N.; Boycko, M.; Shleifer, A.; and Tsukanova, N., (1996). How does privatization work? Evidence from Russian shops. Journal of Political Economy 104 (4): 764-90.

Boubakri, N. and Cosset, J. 1998 .The financial and operating performance of newly-privatized firms: Evidence from developing countries. Journal of Finance 53 (2): 1081-1110.

Boycko, M.; Shleifer, A.; and Vishny, R. 1996. A theory of privatization. Economic Journal 106:309-19.

Bradley, M.; Jarrell, G.; and Kim, H. 1984. On the existence of optimal capital structure: Theory and evidence. Journal of Finance 39 (3): 857-78.

Castianas, R.P. and Helfat, C.E. 1991. Managerial resources and rents. Journal of Management 17 (1): 793-809.

Claessens, S.; Djankov, S.; and Pohl, G. 1997. Ownership and corporate governance: Evidence from the Czech Republic. Policy research paper no. 1737. The World Bank.

D'Souza, J. and Megginson, W. 1999. The financial and operating performance of privatized firms during the 1990s. Journal of Finance 54 (4): 1397-1424.

Earle, J. S. 1998. Post-privatization ownership structure and productivity in Russian industrial enterprises. SITE working paper no. 127. Stockholm School of Economics.

Eckel, C.; Eckel, D.; and Singhal, V. 1997. Privatization and efficiency: Industry effects of the sale of British Airways. Journal of Financial Economics 43 (2): 275-98.

Egyptian Ministry of Public Enterprise. 2001. Privatization Program Performance from the Start to February 2001. Cairo: MPE.

Fiani and Partners, (various issues). Kompass Egypt Financial Year Book. Cairo: Fiani \& Partners.

Field, M. 1995. The slow road to privatization. Euromoney. Middle East Markets Supplement (November, 12-13).

Galal, A.; Jones, L.; Tandon, P.; and Vogelsang, I. 1992. Welfare Consequences of Selling Public Enterprises. Washington, DC: The World Bank.

Gupta, N. 2001. Partial privatization and firm performance: Evidence from India. Working paper no. 426: William Davidson Institute.

Harper, J. 2001. Short-term effects of privatization on performance in the Czech Republic. Journal of Financial Research 24 (1): 119-31.

Jelic, R.; Briston, R.; and Aussenegg, L. 2003. The choice of privatization method and the financial performance of newly privatized firms in transition economies. Journal of Business Finance and Accounting 30 (7-8): 905-40.

Kocenda, E. and Svejnar, J. 2002. The effects of ownership forms and 
concentration on firm performance after large-scale privatization. Working paper no. 471: William Davidson Institute.

LaPorta, R. and Lopez-de-Silanes, F. 1997. Benefits of privatization: Evidence from Mexico. Private Sector 10:21-24.

Martin, S. and Parker, D. 1995. Privatization and economic performance throughout the UK business cycle. Managerial and Decision Economics 16:225-37.

McKinney, B. M. 1996. Recent development in Egyptian investment policies and programs, and pending reform legislation. Middle East Executive Reports 19 (7): 9-12.

Megginson, W.; Nash, ROC.; and Randenborgh, M. 1994. The financial and operating performance of newly privatized firms: An international empirical analysis. Journal of Finance 49 (2): 403-52.

Megginson, W. and J. Netter. 2001. From state to market: A survey on empirical studies on privatization. Journal of Economics Literature 39:321-89.

Muscarella, C.J. and Vetsuypens, M.R. 1990. Efficiency and organizational structure: A study of reverse LBOs. Journal of Finance 45(5):1389-1413.

Oswald, S.L. and Jahera, H.S. JR. 1991. The influence of ownership on performance: An empirical study. Strategic Management Journal 12:321-6.

Ramamurti, R. 1997. Testing the limits of privatization: Argentine railroads. World Development 25:1973-93.

Road, S. 1997. Investing in Egypt. London: Committee for Middle East Trade, (June).

Shleifer, A. R. and Vishny, R. 1997. A survey of corporate governance. Journal of Finance 52 (2):737-78.

Walking, R.A. and Long, M.S. 1984. Agency theory, management welfare, and takeover bid resistance. The Rand Journal of Economics 15 (1):54-68.

Yarrow, G. 1986. Privatization in theory and practice. Economic Policy 1 (2):323-78. 